\title{
The Pathway towards Photoelectrocatalytic Water Disinfection: Review and Prospects of a Powerful Sustainable Tool
}

\author{
Sergi Garcia-Segura ${ }^{1} \mathbb{D}$, Omotayo A. Arotiba ${ }^{2,3}$ and Enric Brillas $^{4, *}$ \\ 1 Engineering Research Center for Nanotechnology-Enabled Water Treatment, School of Sustainable \\ Engineering and the Built Environment, Arizona State University, Tempe, AZ 85287-3005, USA; \\ sergio.garcia.segura@asu.edu \\ 2 Department of Chemical Sciences, University of Johannesburg, Johannesburg 2028, South Africa; \\ oarotiba@uj.ac.za \\ 3 Centre for Nanomaterials Science Research, University of Johannesburg, Johannesburg 2028, South Africa \\ 4 Secció de Química Física, Facultat de Química, Universitat de Barcelona, Martí i Franquès 1-11, 08028 \\ Barcelona, Spain \\ * Correspondence: brillas@ub.edu; Tel.: +34-934021223
}

Citation: Garcia-Segura, S.; Arotiba, O.A.; Brillas, E. The Pathway towards Photoelectrocatalytic Water

Disinfection: Review and Prospects of a Powerful Sustainable Tool. Catalysts 2021, 11, 921. https://doi.org/ 10.3390/catal11080921

Academic Editors: Bruno Fabre and Francesco Basile

Received: 28 June 2021

Accepted: 27 July 2021

Published: 29 July 2021

Publisher's Note: MDPI stays neutral with regard to jurisdictional claims in published maps and institutional affiliations.

Copyright: () 2021 by the authors. Licensee MDPI, Basel, Switzerland. This article is an open access article distributed under the terms and conditions of the Creative Commons Attribution (CC BY) license (https:// creativecommons.org/licenses/by/ $4.0 /)$.
Abstract: Photoelectrocatalysis is a hybrid photon/electron-driven process that benefits from the synergistic effects of both processes to enhance and stabilize the generation of disinfecting oxidants. Photoelectrocatalysis is an easy to operate technology that can be scaled-up or scaled-down for various water treatment applications as low-cost decentralized systems. This review article describes the fundamentals of photoelectrocatalysis, applied to water disinfection to ensure access to clean water for all as a sustainable development goal. Advances in reactor engineering design that integrate light-delivery and electrochemical system requirements are presented, with a description of photo-electrode material advances, including doping, nano-decoration, and nanostructure control. Disinfection and cell inactivation are described using different model microorganisms such as E. coli, Mycobacteria, Legionella, etc., as well the fungus Candida parapsilosis, with relevant figures of merit. The key advances in the elucidation of bacterial inactivation mechanisms by photoelectrocatalytic treatments are presented and knowledge gaps identified. Finally, prospects and further research needs are outlined, to define the pathway towards the future of photoelectrocatalytic disinfection technologies.

Keywords: photoelectrocatalysis; drinking water treatment; decentralized disinfection; photocatalyisis; electrochemical advanced oxidation process; UV light and sunlight; $\mathrm{TiO}_{2}$; Escherichia coli; Mycobacteria; Candida parapsilosis

\section{Introduction}

The access to clean drinking water is essential to every person's life and was acknowledged as a human right by the United Nations (UN) in 2010 [1]. Despite recent advances, more than 2.2 billion people still lack access to safe drinking water and 4.2 billion lack safely managed sanitation [2]. These limitations were exacerbated during the COVID-19 pandemic, given the fact that more than 3 billion people worldwide do not have access to basic handwashing facilities at home [3,4]. Thus, access to clean water and sanitation for all is part of the roadmap towards sustainable development and equity, as defined by the $\mathrm{UN}[5,6]$.

The implementation of a public supply of safe drinking water at the beginning of the 20th century in the USA increased the lifespan of Americans by the astonishing number of 16 years between 1900 and 1947 [7]. Unfortunately, in the 21st century 3 in 10 people still lack access to safe drinking water services. Nearly 1000 children die daily due to avoidable diarrheal and other bacterial diseases [8]. Waterborne pathogen diseases can be prevented by effective water disinfection treatment.

One of the identified barriers to equitable access to water is a matter of environmental justice. Environmental justice considers the fair treatment and meaningful involvement of 
all people with respect to development, implementation, and enforcement of environmental laws, regulations, and policies (regardless of income, race, etc.) [9]. Access to drinking water is not an exception. One of the major barriers to equal access is associated with the high capital investment and maintenance of infrastructure and water distribution systems. The high costs of conventional centralized water treatment plants may make them unviable, especially in developing regions [10]. In this frame, decentralized technologies may play a key role in ensuring safe water for human wellbeing [11].

Decentralized water treatment involves the use of systems located at or near to the site where drinking water will be used by a small community and are usually referred to as small drinking water systems. This is a flexible and sustainable alternative that requires lower capital expenditure than large and centralized treatment plants. Pointof-entry (POE) treatments treat the water entering a community or a building to reduce the health risks associated with waterborne contaminants in drinking water. Meanwhile, point-of-use (POU) treatments treat water at the point of consumption. These POE and POU technologies can be either the only and/or the final barrier to pathogens in water to be consumed. However, these small drinking water systems must be easy to operate by untrained consumers, compact, implementable as water and electrical off-grid technology, and affordable. Otherwise, these systems will become a barrier to equal access. As such, light-driven processes have demonstrated their high competitiveness and user-friendly deployability by meeting all these requirements.

Photoelectrocatalysis (PEC) is an emerging light-driven technology that recent studies have shown to be a highly adaptable and competitive approach in different scenarios, from centralized to portable individualized disinfection devices. This review article presents the fundamental principles of PEC as applied to disinfection. Note that the objective of disinfection is to inactivate pathogen microorganisms, usually by $99.99 \%$. However, this concept should not be confused with sterilization, which implements more drastic methods to attain complete destruction of living organisms (100\%) and their resistant structures (e.g., spores and prions), and which are not removed by disinfection treatments. Disinfection is usually applied in a sanitization context, with the aim of providing safe drinking water, while sterilization is conventionally used when extreme cleanliness is required (e.g., hospitals, surgeries). These two concepts must not be confused. In this review article we thoroughly address disinfection applications. Photoelectrochemical systems and reactor designs for disinfection processes are described and disinfection performance discussed for different target pathogenic microorganisms. Bacteria inactivation by direct and indirect photoelectrocatalytic mechanisms are presented, identifying fundamental research needs. Finally, a prospect section describes the steps and knowledge gaps that should be addressed to promote the translation of the technology to higher technological readiness levels and different application scales.

\section{Bibliometric Analysis}

Reviews and scientific articles related to the photoelectrocatalytic disinfection of microorganisms in wastewater were exhaustively searched for in the Scopus database at the end of April 2021, with the following keywords: Photoelectrocatalysis AND disinfection, and Photoelectrocatalysis AND bacteria. The first scientific articles on this topic were found in 2006, and only publications (reviews and scientific articles) written in English were selected within a period from 2006 to 2021. The authors, title, abstract, and references of each retrieved publication were listed and analyzed individually. This analysis excluded communications in congresses, conferences, and book chapters. The publications included in this review were selected on the following criteria:

1. the correct usage of the PEC method,

2. the disinfection of synthetic and real wastewaters,

3. an appropriate description of the experimental methodology used, with information about the photoelectrochemical system, the kind of cell and electrodes studied, the 
artificial lamp or natural light used for irradiation, adequate operating conditions, and the equipment for analysis and quantification of microorganisms,

4. a detailed discussion of the results obtained, mainly regarding the synthesis and analysis of the photoanodes, the pathogen inactivation with electrolysis time and operating variables, the effect of the aqueous matrix and organic components, the assessment of the disinfecting agents used to explain the inactivation mechanism, and the presentation of SEM images to show the morphological changes to the inactivated bacteria. The measurement of the decay of total organic carbon (TOC) of real wastewater was also considered. Comparison with anodic oxidation $(\mathrm{AO})$ and photocatalysis $(\mathrm{PC})$ under the same conditions was useful to identify the synergistic or additive character of the photoelectrocatalytic treatment.

Apart from the above publications, several papers were selected to better understand the disinfecting agents and byproducts formed during the PEC process, as well as the nature of the semiconductor materials synthesized as photoanodes.

Following the above criteria, two key review articles were identified describing some aspects of bacteria disinfection. One of these reviews reported general information on the environmental and energy application of PEC, covering up to 2015 [12], whereas the other was more recent and rather centered on the explanation of large photoreactors for producing disinfecting agents in synthetic and real wastewaters [13]. However, a specific and critical review, such as the one presented here, on the inactivation of microorganisms by PEC has not been previously reported in the literature.

The bibliometric analysis was completed by identifying 38 scientific articles related to the photoelectrocatalytic disinfection of microorganisms. A large number of papers were published after 2017 (47.4\%), disclosing the current growing interest in this technology for water disinfection. Regarding the pathogens inactivated, Escherichia coli was the preferred pathogen model to be inactivated (65.8\% in 25 articles), followed by Mycobacteria ( $13.2 \%$ in 5 articles) and the fungus Candida parapsilosis (10.5\% in 4 articles). The inactivation of other bacteria including Pseudonomas aeruginosa, Legionella pneumophila, Microcystin aeruginosa and so on, were studied to a much smaller extent (10.5\% in 4 articles).

\section{Characteristics of Photoelectrocatalysis}

The photocatalytic effect of semiconductor materials was first reported in the groundbreaking work of Fujishima and Honda in 1972 [14]. PEC is a hybrid technology that benefits from the synergistic interactions of light-driven and electron-driven processes [12,15,16]. The irradiation of a semiconductor material with photons of energy superior to the characteristic bandgap energy $\left(E_{\mathrm{g}}\right)$ can photoexcite an electron from the full valence band (VB) of a semiconductor material to the empty conduction band (CB) [17-19]. The electron photoexcitation $\left(\mathrm{e}_{\mathrm{CB}}{ }^{-}\right)$simultaneously generates a positive vacancy or hole in the $\mathrm{VB}$ $\left(\mathrm{h}_{\mathrm{VB}}{ }^{+}\right)$following Reaction (1) [20,21]. These two species, known as charge carriers, present redox properties that can be exploited in heterogeneous catalytic processes. The $\mathrm{e}_{\mathrm{CB}}{ }^{-}$are reducing agents and the $\mathrm{h}_{\mathrm{VB}}{ }^{+}$are strong oxidants. When semiconductors are in contact with aqueous solutions, both $\mathrm{e}_{\mathrm{CB}}{ }^{-}$and $\mathrm{h}_{\mathrm{VB}}{ }^{+}$generate reactive oxygen species (ROS) that have bactericidal effects $[22,23]$. The photogenerated $\mathrm{h}_{\mathrm{VB}}{ }^{+}$can oxidize water to hydroxyl radicals following Reaction (2). Meanwhile, the $\mathrm{e}_{\mathrm{CB}}{ }^{-}$can react with dissolved oxygen yielding superoxide radicals from Reaction (3).

$$
\begin{aligned}
\text { Semiconductor }+h v & \rightarrow \mathrm{e}_{\mathrm{CB}}{ }^{-}+\mathrm{h}_{\mathrm{VB}}{ }^{+} \\
\mathrm{h}_{\mathrm{VB}}{ }^{+}+\mathrm{H}_{2} \mathrm{O} \rightarrow \bullet & \mathrm{OH}+\mathrm{H}^{+} \\
\mathrm{e}_{\mathrm{CB}}{ }^{-}+\mathrm{O}_{2} & \rightarrow \mathrm{O}_{2}{ }^{-}
\end{aligned}
$$

The main limitation of purely photon-driven photocatalytic processes is the short time of life of the charge carriers $\left(\mathrm{e}_{\mathrm{CB}}{ }^{-}\right.$and $\left.\mathrm{h}_{\mathrm{VB}}{ }^{+}\right)$, which tend to recombine to return to the ground state, according to Reaction (4). This is supported by the average low life-time 
of charge carriers; $<14$ ns was reported for several semiconductor materials produced by photocatalysis applied to water treatment [24].

$$
\mathrm{e}_{\mathrm{CB}}{ }^{-}+\mathrm{h}_{\mathrm{VB}}{ }^{+} \rightarrow \text { heat }
$$

Here is where the electrification of photocatalysis provides an efficient solution to the drawbacks of the recombination reaction. When the semiconductor under irradiation is simultaneously employed as an electrode, the recombination reaction can be markedly reduced $[25,26]$. With the application of a bias potential to the semiconductor or a constant current, the charge carriers are separated by the induced electrical field, minimizing recombination rates, as illustrated in Figure 1. The prevention of charge recombination in the photoelectrocatalytic system is essential to maximize the efficient generation of $\mathrm{e}_{\mathrm{CB}}{ }^{-}$and $\mathrm{h}_{\mathrm{VB}}{ }^{+}$and their utilization in the process of interest: water disinfection $[27,28]$. Experimental results demonstrate a stark acceleration of the kinetic rate of organic pollutant abatement and bacterial inactivation.

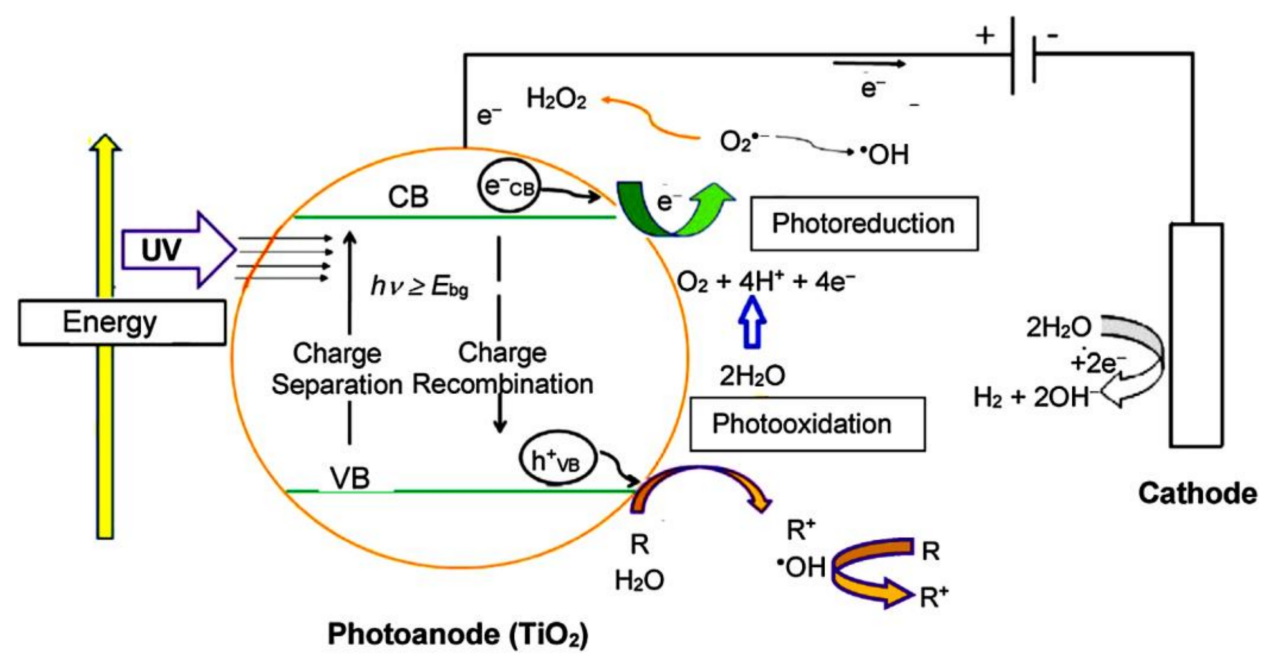

Figure 1. Mechanism of PEC process using $\mathrm{TiO}_{2}$ photocatalyst. Reproduced from [15].

\section{Photoanodes for Disinfection and Photoelectrochemical Systems}

The selection of photoanode material is essential for defining the disinfection performance of photoelectrocatalytic systems. Photoanodes are semiconductor materials generally based on metal oxides. Titania $\left(\mathrm{TiO}_{2}\right)$ is the most studied material in environmental remediation and water disinfection $[18,29]$. $\mathrm{TiO}_{2}$ is an $n$-type semiconductor that presents three photoactive crystalline structures: rutile, anatase, and brookite. The most common nanostructure exploited in photoelectrocatalytic systems is $\mathrm{TiO}_{2}$ nanotubes (NTs) or sol-gel coatings on conductive substrates, as shown in Figure $2 \mathrm{a}, \mathrm{b}[30,31]$. All the $\mathrm{TiO}_{2}$ forms have $E_{\mathrm{g}}$ values within the range of $3.0-3.3 \mathrm{eV}$. The anatase structure is the most used crystalline phase, given its higher activity under UV irradiation. However, the main limitation of $\mathrm{TiO}_{2}$ photoelectrodes is associated with their low photo-response under natural sunlight irradiation, which only contains $<4.0 \%$ of the UV light component within the entire solar spectrum [18,32]. This is a major limitation in developing regions with limited access to water and energy grids, due to the energy intensive requirements of conventional lamps. There are several solutions that have been considered to overcome this translational barrier, which will be discussed herein: (i) use of alternative semiconductor photoelectrodes, (ii) doping and nanodecoration of semiconductors, and (iii) the use of light-emitting diodes (LEDs) as the most recent tool for decentralized water treatment.

The photoelectrocatalytic disinfection studies summarized in Table 1 highlight the major focus on the use of $\mathrm{TiO}_{2}$, due to their innocuous character and well-known behavior in PEC. However, there are emerging studies and increasing interest in alternative photoelectrocatalytic materials. This is the case for $\mathrm{ZnO}$ as an $n$-type disinfecting semiconductor, 
which has been used under solar irradiation [33]. ZnO is a versatile semiconductor that can be shaped into alternative nanostructures such as fern-like structures [34], nanorods [35], nano-shaped coils [36], and other biomimetic structures [37], as can be seen in Figure 2c,e. Unfortunately, this material has been little studied in the context of disinfection applications. Similar nanorod structures can be obtained with copper oxides (see Figure 2f) [38]. In contrast, the use of $\mathrm{WO}_{3}$ as an $n$-type semiconductor has been reported [39]. The lower $E_{\mathrm{g}}$ of tungsten oxide $\left(\mathrm{WO}_{3}\right)$, around 2.5-2.7 eV, pinpoints this semiconductor as a promising alternative for natural sunlight photocatalysis [40]. Nevertheless, the wide availability and inexpensive traits of $\mathrm{TiO}_{2}$ are hardly bettered by $\mathrm{WO}_{3}$, given that tungsten is an endangered element that may not be suitable long term, when considering life cycle analyses [41]. This is probably the main reason why research has focused on the modification of pristine $\mathrm{TiO}_{2}$ with doping or manufacturing nanocomposites.
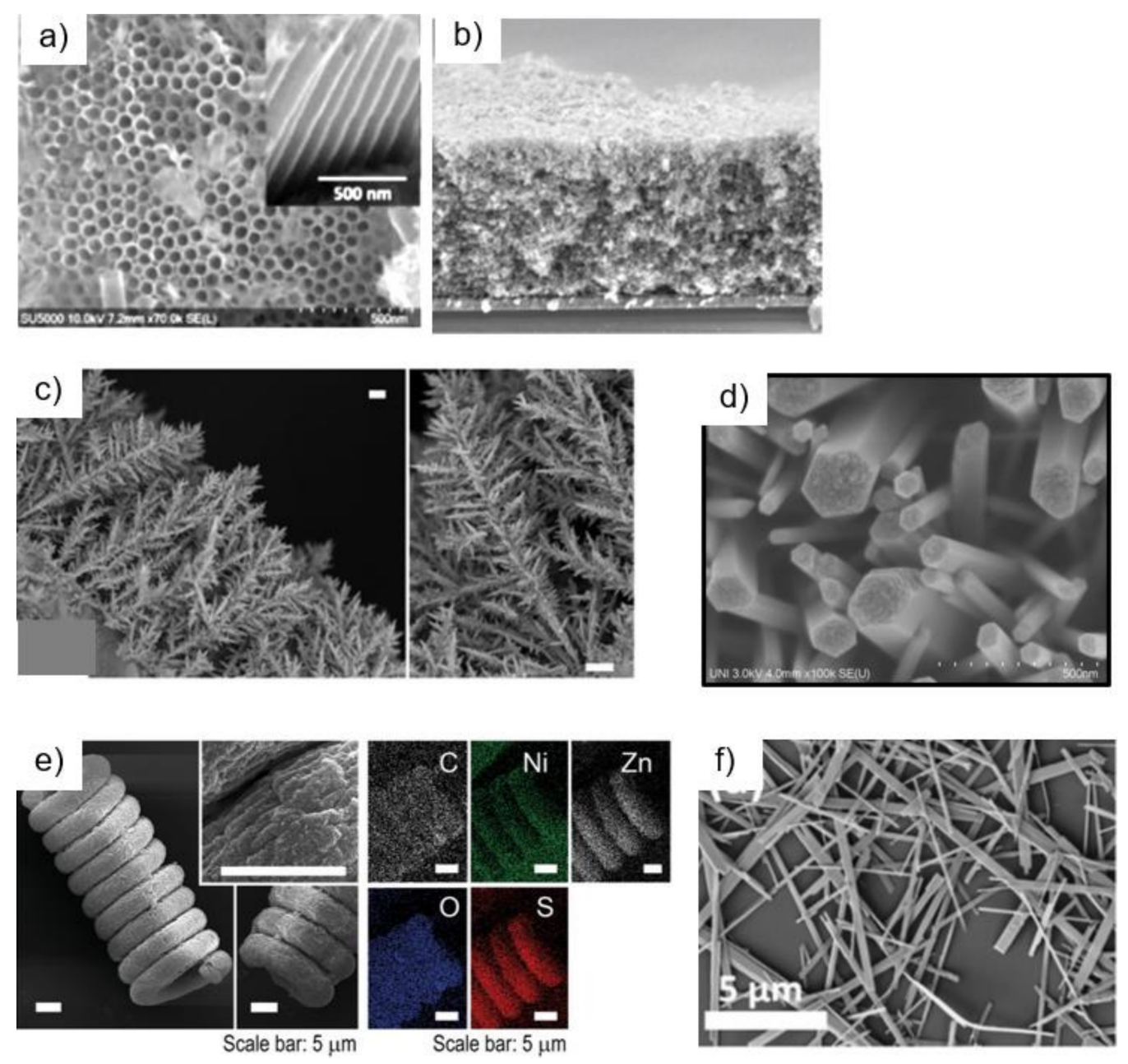

Figure 2. SEM images of various synthesized semiconductor materials for photon-driven applications. (a) $\mathrm{Ti} / \mathrm{TiO} 2$ nanotubes (NTs) (reproduced from [30]), (b) sol-gel $\mathrm{TiO}_{2}$ coating (reproduced from [31]), (c) ZnO fern-like structure (reproduced from [34]), (d) $\mathrm{ZnO}$ nanorods (reproduced from [35]), (e) $\mathrm{ZnO}$ coils (reproduced from [36]), and (f) CuOnanorods (reproduced from [38]).

The doping of semiconductors is an approach that inserts intraband levels that decrease the $E_{\mathrm{g}}$ value required in the photoexcitation step (1) [42,43]. Elements introduced can replace titanium/oxygen atoms (substitutional doping) or can be inserted in the interstices of the existing crystallographic lattice (interstitial doping). Decreasing the photon energy required for Reaction (1) widens the range of the irradiation wavelength that can result in the efficient photogeneration of charge carriers and disinfectants. The other modifica- 
tion approach consists of the generation of nanocomposites by generating interfaces of metal/semiconductor or semiconductor/semiconductor [22,44,45]. While doping does not affect the structural aspects of the semiconductor, nanodecoration shows characteristic differences between pristine and modified materials (see Figure 2c). The presence of these interfaces generates a Schottky barrier, stabilizes the charge carriers, and delays the recombination Reaction (4). Furthermore, the implementation of antibacterial metals such as silver can result in a synergistic disinfection activity, by enacting bacterial inactivation mechanisms.

Finally, the addition of UV-LEDs to the water treatment tool-box has opened an avenue that can revolutionize photon-driven compact systems [32,46]. The most relevant aspect is that the high photon conversion efficiency and the low quantity of energy required can lift the techno-economic aspects that were the main roadblock for the translational application of photocatalytic and photoelectrocatalytic systems: the operational expenses of lamps.

\section{Engineered Photoelectrochemical Systems}

Photoelectrocatalytic disinfection has been demonstrated to be very effective, as summarized in Table 1. Scientific results suggest that photoelectrocatalytic treatment can become a competitive solution for the decentralized, quick disinfection of drinking water sources. However, there is a major engineering challenge to translate small laboratory set-ups into competitive reactor engineering settings. The most pressing need is to identify reactor designs that marry the needs for an efficient light delivery of photons from the light source (e.g., natural sunlight, UV-lamp, LEDs, etc.) with the required components of an electrochemical reactor that is connected to an electrical circuit, while maintaining the cathode and photoanode in a parallel position. One of the most obvious challenges is the light transport into a cell that contains two-dimensional electrodes positioned in a flow- by system. Designs try to overcome this challenge with different engineering approaches.

Figure 3 shows five designs that consider different light-delivery approaches in a batch reactor. The scheme of Figure 3a illustrates a photoelectrode plate placed perpendicularly to the light irradiation source (natural sunlight) to maximize the usage of direct radiation in an undivided cell $[47,48]$. Positioning the electrode closer to the upper-surface of the solution can also contribute to minimizing the photon absorption by the compounds in the solution, therefore enhancing the yield of disinfectant species. Meanwhile, the design of Figure $3 \mathrm{~d}$ mostly considers the hydrodynamic needs of transport in an undivided batch reactor, at the expense of decreasing the effective photon irradiation by positioning the electrodes parallel to the natural sunlight [49]. Figure $3 c$ shows an undivided cell with an inner UV lamp that irradiates perpendicularly to the electrodes [47]. This approach is one of the most commonly used in laboratory settings but may be non-operational for the treatment of larger volumes of solution. Note that the uneven radiation penetration can result in a non-uniform photo-activity of the photoelectrode. When trying to face the challenge of effective light-delivery, some researchers have proposed the immersion of lamps within the solution, as previously done for photocatalytic systems by positioning the electrodes around a quartz jacketed UV-lamp source. This design approach improves the light irradiation but induces a larger interelectrode-gap distance, implying larger electrical costs and the requirement for higher conductivities in the solution. 
a)
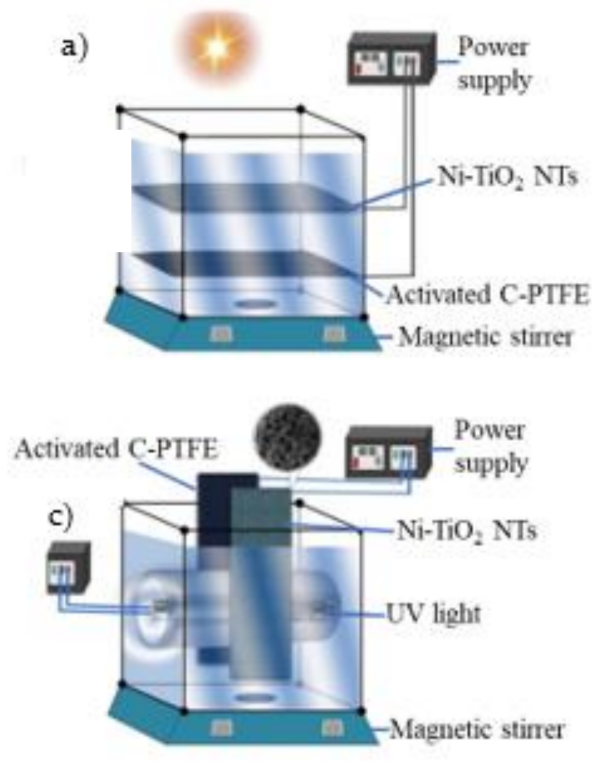

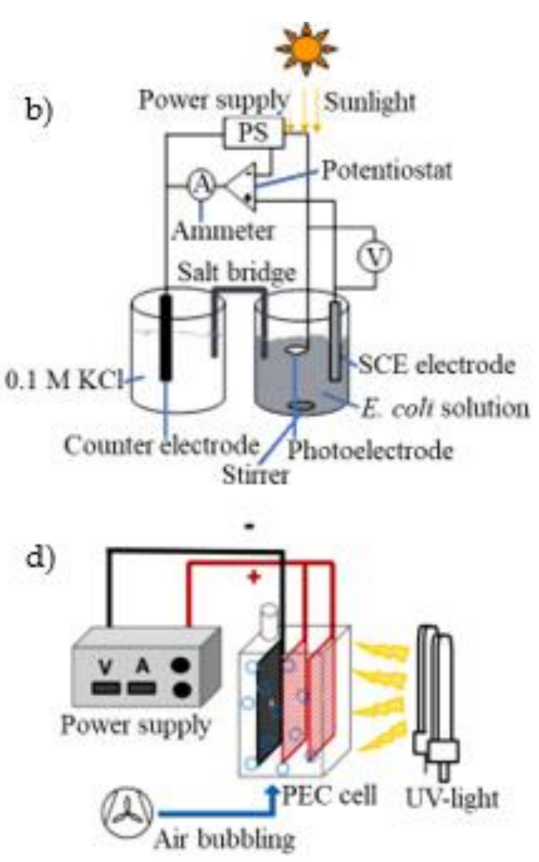

e)

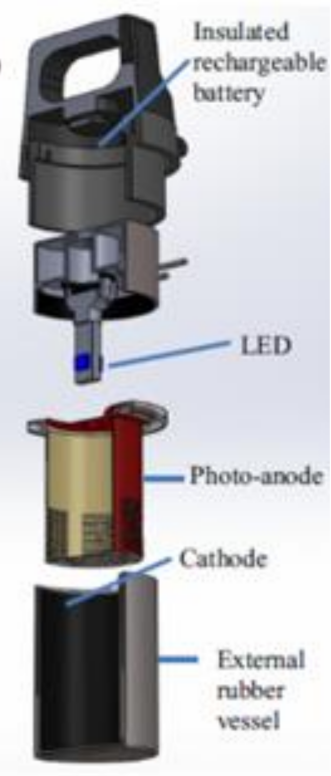

Figure 3. Sketches of setups of PEC systems. Undivided two-electrode rectangular tank reactor with (a) horizontal electrodes upon sunlight and (c) vertical electrodes illuminated with an inner UV light (adapted from [47]). (b) Divided three-electrode cell upon solar irradiation for solar PC (SPC), anodic oxidation (AO), and solar PEC (SPEC) (adapted from [49]). (d) Undivided two-electrode tank reactor with the photoanode (in red) irradiated with external UV light (adapted from [30]). (e) Portable autonomous photoelectrocatalytic disinfection device (reproduced from [28]).

The development of thin transparent semiconductor coatings on glass surfaces, such as indium-doped tin oxide (ITO) and fluorine-doped tin oxide (FTO), has opened avenues to use an external radiation source utilizing these electrodes as a window into the photoelectrochemical cells [30]. This engineered approach benefits from the direct usage of light, while maintaining the conventional electrochemical cell designs of electrochemical filter-press cells. However, this may result in a larger unit physical footprint, because of the required window of irradiation, as can be seen in Figure $3 b$ [30].

The recent implementation of LEDs may revolutionize reactor design. For instance, Figure 3e depicts a scaled-down portable and autonomous photoelectrocatalytic device for disinfection [28]. The compact water flask-like design tries to maximize the know-how of batch-systems, while providing the portable capability of a compact design. The solution vessel includes a cylindrical cathode with a concentrically inserted photoanode. This design maintains a small interelectrode gap distance, while providing an even irradiation of the photo-anode surface for effective generation of disinfectants in-situ. Similar design and engineering advances may be inspired by the LED's compact, versatile, and adaptable capabilities. Nevertheless, it becomes evident that developing a new reactor design is one of the major needs for the advancement of photoelectrocatalytic technologies and to enable access to clean water for all. 
Table 1. Selected results obtained for the inactivation of bacteria by photoelectrocatalysis (PEC).

\begin{tabular}{|c|c|c|c|c|}
\hline System & Medium & Experimental Conditions & Best Results & Ref \\
\hline \multicolumn{5}{|l|}{ Escherichia coli } \\
\hline $\begin{array}{l}\text { Stirred undivided three-electrode tank reactor } \\
\text { with an inner } 9 \text { W UVA lamp }\end{array}$ & $\begin{array}{l}500 \mathrm{~mL} \text { of } 10^{3} \mathrm{CFU} \mathrm{mL}^{-1} \text { E. coli in pure water } \\
\text { with } 0.10 \mathrm{M} \mathrm{Na}_{2} \mathrm{SO}_{4} \text { at } \mathrm{pH} 5.6 \text { and } 25^{\circ} \mathrm{C}\end{array}$ & $\begin{array}{r}\mathrm{TiO}_{2} \text { deposited onto } \mathrm{Ti} \text { as photoanode, } \mathrm{SS}^{\mathrm{a}} \\
\text { wire cathode surrounding the UVA lamp, } \\
\text { and } \mathrm{Ag} \mid \mathrm{AgCl} \text { reference electrode. } E_{\mathrm{an}}{ }^{\mathrm{b}}= \\
+1.0 \mathrm{~V} / \mathrm{Ag} \mid \mathrm{AgCl}\end{array}$ & $\begin{array}{l}11 \% \text { cell inactivation by } \mathrm{AO}^{\mathrm{C}} \text { in } 120 \mathrm{~min} \text {, and } \\
\text { total cell disinfection by } \mathrm{PC} \text { in } 105 \mathrm{~min} \text { and } \\
\text { PEC in } 60 \mathrm{~min} \text {. }\end{array}$ & [50] \\
\hline $\begin{array}{l}\text { Similar to Figure 3d illuminated with an } \\
\text { external } 4 \text { W UVA light }\end{array}$ & $\begin{array}{c}50 \mathrm{~mL} \text { of } 1.6 \times 10^{9} \mathrm{CFU} \mathrm{mL}^{-1} \text { fecal coliforms } \\
\left(1.2 \times 10^{6} \mathrm{CFU} \mathrm{mL}^{-1} \mathrm{E} \text {. coli) in real urban }\right. \\
\text { wastewater at } \mathrm{pH} 7.9\end{array}$ & $\begin{array}{c}\mathrm{Al} \mid \mathrm{TiO}{ }_{2} \text { or } \mathrm{Al} / \mathrm{TiO}_{2}-\mathrm{Ag} \text { photoanode, and } \mathrm{Al} \\
\text { cathode. Cell voltage }=0.5-1.5 \mathrm{~V}\end{array}$ & 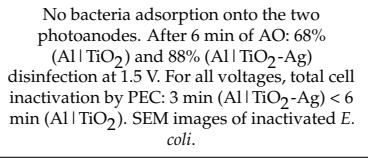 & [23] \\
\hline $\begin{array}{l}\text { Flow-through undivided three-electrode } \\
\text { thin-layer cell with a quartz window. UV-LED } \\
\qquad(\lambda=365 \mathrm{~nm}) \text { light of } 8 \mathrm{~mW} \mathrm{~cm}^{-2}\end{array}$ & $\begin{array}{l}9.0 \times 10^{6} \mathrm{CFU} \mathrm{mL}^{-1} \text { E. coli in pure water with } \\
0.1 \mathrm{M} \mathrm{NaNO}_{3} \text {, in the presence or absence of } 1.0 \\
\mathrm{mM} \mathrm{NaCl} \text { or } \mathrm{NaBr}\end{array}$ & $\begin{array}{c}\mathrm{ITO} \mathrm{d} \mid \mathrm{TiO}_{2} \text { photo-anode, } \mathrm{Pt} \text { disc cathode, } \\
\text { and } \mathrm{Ag} \mid \mathrm{AgCl} \text { reference electrode. } E_{\text {an }}=+0.3 \\
\mathrm{~V} / \mathrm{Ag} \mid \mathrm{AgCl}\end{array}$ & $\begin{array}{l}\text { Overall disinfection by PEC in: } 1.57 \mathrm{~s} \text { with } \\
\mathrm{Br}^{-}<23.3 \mathrm{~s} \text { with } \mathrm{Cl}^{-}<311 \mathrm{~s} \text { without these } \\
\text { ions. Bactericide action of } \mathrm{Br}^{-}-/ \mathrm{Br}_{2}{ }^{--} \text {. }\end{array}$ & [51] \\
\hline $\begin{array}{l}\text { Undivided three-electrode tank reactor with a } \\
\text { quartz window to irradiate with external } 150 \mathrm{~W} \\
\text { Xe lamp filtered to obtain UV and visible light. }\end{array}$ & $\begin{array}{l}45 \mathrm{~mL} \text { of } 10^{7} \mathrm{CFU} \mathrm{mL}^{-1} \text { E. coli in pure water } \\
\text { with } 0.10 \mathrm{M} \mathrm{NaNO}_{3}\end{array}$ & $\begin{array}{l}\mathrm{FTO}^{\mathrm{f}} \mid(1111) \text { rutile } \mathrm{TiO}_{2} \text { photoanode, } \mathrm{Pt} \\
\text { mesh cathode, and } \mathrm{Ag} \mid \mathrm{AgCl} \text { reference } \\
\text { electrode. } E_{\mathrm{an}}=+0.4 \mathrm{~V} / \mathrm{Ag} \mid \mathrm{AgCl}\end{array}$ & $\begin{array}{l}\text { Disinfection: } 2 \% \text { (photolysis) < } 12 \% \text { (AO). } \\
\text { Overall cell inactivation with UV: } 30 \text { min (PC } \\
\text { e) }>10 \text { min (PEC). Direct sunlight gave total } \\
\text { disinfection in } 2 \text { min. }\end{array}$ & [52] \\
\hline $\begin{array}{l}\text { Undivided three-electrode tank reactor } \\
\text { submitted to an external } 30 \text { W UVA lamp }\end{array}$ & $\begin{array}{c}10^{6} \mathrm{CFU} \mathrm{mL}^{-1} \text { E. coli in pure water with } 0.01 \% \\
\mathrm{NaCl} \text { at pH } 5.2\end{array}$ & $\begin{array}{c}\mathrm{Ti} \mid \mathrm{TiO}_{2} \mathrm{NTs}_{\mathrm{s}} \mathrm{g} \text { photoanode, } \mathrm{Pt} \text { cathode, and } \\
\mathrm{SCE} \text { reference electrode. } E_{\mathrm{an}}=+0.2-5.0 \\
\text { V/SCE }\end{array}$ & $\begin{array}{l}\text { More rapid disinfection by PEC than PC } \mathrm{e} \text {. } \\
\text { Decreasing time for total cell inactivation: } 30 \text {, } \\
20,15 \text {, and } 10 \mathrm{~min} \text { at } E_{\text {an }} \text { of }+0.2,+1.0,+2.0, \\
\text { and }+3.0 \mathrm{~V} \text {, respectively. }\end{array}$ & [53] \\
\hline $\begin{array}{l}\text { Stirred undivided three-electrode tank reactor } \\
\text { with air bubbling, submitted to an external } 450 \\
\text { W Xe lamp for UVV-Vis and also filtered at } \lambda> \\
420 \mathrm{~nm} \text { for visible light }\end{array}$ & $\begin{array}{l}15 \mathrm{~mL} \text { of } 10^{6} \mathrm{CFU} \mathrm{mL}^{-1} \text { E. coli in } \frac{1}{4} \text { strength } \\
\text { Ringers solution at } 25^{\circ} \mathrm{C}\end{array}$ & $\begin{array}{c}\mathrm{Ti} \mid \mathrm{TiO}_{2} \mathrm{NTs} \text { or } \mathrm{Ti} \mid \mathrm{N}-\mathrm{TiO}_{2} \mathrm{NTs} \text {, Pt mesh } \\
\text { cathode, and } \mathrm{Ag} \mid \mathrm{AgCl} \text { reference electrode. } \\
E_{\mathrm{an}}=+1.0 \mathrm{~V} / \mathrm{Ag} \mid \mathrm{AgCl}\end{array}$ & 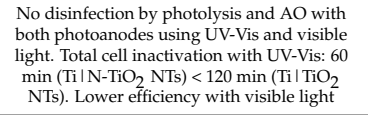 & [54] \\
\hline Figure $3 \mathrm{~d}$ with an external $18 \mathrm{~W}$ UVA light & $\begin{array}{c}190 \mathrm{~mL} \text { of } 10^{6} \mathrm{CFU} \mathrm{mL}^{-1} \text { E. coli in surface } \\
\text { water at } \mathrm{pH} 7.4\end{array}$ & $\begin{array}{c}\mathrm{Ti} \mid \mathrm{TiO}_{2}-\mathrm{NTs} \text { photo-anode, and a Ti } \mid \mathrm{Pt} \text { or } \\
\text { carbon felt (for } \mathrm{H}_{2} \mathrm{O}_{2} \text { production) cathode. } \\
\text { Cell voltage }=1 \mathrm{~V} \text { for } 120 \mathrm{~min}\end{array}$ & $\begin{array}{l}\text { Log units cell reduction for Ti I Pt: } 0.04 \text { (AO) } \\
<1.00(\mathrm{PC} \mathrm{e})<2.40 \text { (PEC). Faster disinfection } \\
\text { in the presence of organic micropollutants, } \\
\text { more rapid with } 5 \mathrm{mM} \text { of hole acceptor. }\end{array}$ & [30] \\
\hline $\begin{array}{c}\text { Similar to Figure } 3 \mathrm{c} \text { with air bubbling, an inner } 6 \\
\text { W UVA lamp, and a central basket with } \mathrm{TiO}_{2} \\
\text { supported onto GAC }\end{array}$ & $\begin{array}{c}10^{3} \mathrm{CFU} \mathrm{mL}^{-1} \text { E. coli in synthetic fish farm } \\
\text { wastewater at } \mathrm{pH} 6.2\end{array}$ & $\begin{array}{c}\mathrm{Pt} \mid \mathrm{RuO}_{2} \text { anode and SS cathode both of } 100 \\
\mathrm{~cm}^{2} \text { area. } j^{\mathrm{i}}=0.03-0.10 \mathrm{~mA} \mathrm{~cm}^{-2} \text { for } 120 \\
\min \end{array}$ & $\begin{array}{c}\text { Log units cell reduction increased as: } 0.50 \\
(\mathrm{AO}, 0.03 \mathrm{~mA} \mathrm{~cm}-2)<0.72\left(\text { photolysis }^{-2}<\right. \\
1.05\left(\mathrm{PEC}, \mathrm{GAC}-\mathrm{TiO}_{2}, 0.03 \mathrm{~mA} \mathrm{~cm}^{-2}\right)<1.25 \\
\left(\mathrm{PC}^{\mathrm{e}}, \mathrm{GAC}\right)<2.75\left(\mathrm{PEC},{\mathrm{GAC}-\mathrm{TiO}_{2}, 0.06} \mathrm{~mA} \mathrm{~cm}^{-2}\right)<2.95\left(\mathrm{PEC}, \mathrm{GAC}-\mathrm{TiO}_{2}, 0.10 \mathrm{~mA}\right. \\
\left.\mathrm{cm}^{-2}\right) \text {. Determination of total chlorine and } \\
\text { the rate of hydroxyl radical }\end{array}$ & \\
\hline $\begin{array}{l}\text { Stirred undivided three-electrode tank reactor } \\
\text { upon an external } 300 \mathrm{~W} \text { Xe lamp filtered } \\
\text { cutting-off } \lambda<420 \mathrm{~nm} \text { (visible light) }\end{array}$ & $\begin{array}{l}50 \mathrm{~mL} \text { of } 10^{7} \mathrm{CFU} \mathrm{mL}^{-1} \text { E. coli in pure water } \\
\text { with } 0.2 \mathrm{M} \mathrm{NaNO}_{3}\end{array}$ & $\begin{array}{l}\mathrm{N} \text {-doped carbonaceous } \mid \mathrm{TiO}_{2} \text { photo-anode } \\
\text { (prepared at } 120-180^{\circ} \mathrm{C} \text { hydrothermal } \\
\text { temperatures,) } \mathrm{Pt} \text { cathode, and } \mathrm{Ag} \mid \mathrm{AgCl} \\
\text { reference electrode. } E \mathrm{an}=+1.0 \mathrm{~V} / \mathrm{Ag} \mid \mathrm{AgCl}\end{array}$ & $\begin{array}{l}\text { Solution not disinfected by } \mathrm{AO} \text { and } \\
\text { photolysis. Total cell inactivation: } 40 \mathrm{~min} \\
\text { (PEC) < } 90 \mathrm{~min}(\mathrm{PC} \mathrm{e}) \text { using a composite } \\
\text { synthesized at } 150^{\circ} \mathrm{C} \text {. Higher photocurrent } \\
\text { density and faster disinfection }(30 \mathrm{~min}) \text { by } \\
\text { decreasing synthesis temperature at } 120^{\circ} \mathrm{C}\end{array}$ & [55] \\
\hline Figure $3 \mathrm{~b}$ upon direct sunlight & $\begin{array}{l}100 \mathrm{~mL} \text { of } 10^{5} \mathrm{CFU} \mathrm{mL}-1 \text { E. coll in pure water } \\
\text { as anolyte and } 100 \mathrm{~mL} \text { of } 0.1 \mathrm{M} \mathrm{KCl} \text { as catholyte }\end{array}$ & $\begin{array}{c}{\mathrm{Ag}-\mathrm{TiO}_{2}} \text { graphite as photoanode, graphite } \\
\text { rod cathode, and SCE reference electrode. } \\
\text { Cell voltage }=3 \mathrm{~V} \text { for } 30 \mathrm{~min}\end{array}$ & $\begin{array}{c}\text { Percent of cell inactivation and rate constant } \\
\mathrm{CFU} \mathrm{mL}^{-1} \min ^{-1}: 34 \%, 0.014 \text { (photolysis) } \\
<72 \%, 0.038 \text { (PC } \mathrm{PC})<78 \%, 0.044\left(\mathrm{SPECC}^{\mathrm{j}}\right)< \\
83 \%, 0.051 \text { (AO). Auto-oxidation of Ag in AO } \\
\text { and SPEC }\end{array}$ & [49] \\
\hline $\begin{array}{l}\text { Similar to Figure } 3 \mathrm{~d} \text { upon external illumination } \\
\text { with a } 400 \mathrm{~W} \text { UV-Vis lamp filtered for providing } \\
\text { visible light }(\lambda \max =510 \mathrm{~nm})\end{array}$ & $\begin{array}{l}100 \mathrm{~mL} \text { of } 1.2 \mathrm{mg} \mathrm{L}^{-1} 17 \alpha \text {-ethinylestradiol + } \\
10^{9} \mathrm{CFU} \mathrm{mL}^{-1} \text { E. coli in pure water with } 100 \\
\mathrm{mM} \mathrm{Na}_{2} \mathrm{SO}_{4} \text { at pH } 4.0 \text {-and } 20^{\circ} \mathrm{C}\end{array}$ & $\begin{array}{c}\mathrm{Ti}_{\mathrm{i}} \mathrm{TiO}_{2}-\mathrm{Ag} \mid \mathrm{SnO}_{2}-\mathrm{Sb} \text { photoanode and } \\
\text { carbon-PTFE cathode. } j=4.0 \mathrm{~mA} \mathrm{~cm}^{-2} \text { for } \\
60 \mathrm{~min}\end{array}$ & $\begin{array}{l}\text { Percentage of } 17 \alpha \text {-ethinylestradiol removal } \\
\text { and log units cell reduction: } 3 \% \text { and } 4.4 \\
\text { (photolysis), } 34 \% \text { and } 4.1(\mathrm{AO}), 19 \% \text { and } 4.7 \\
\left(\mathrm{PC} \mathrm{e}^{\mathrm{e}} \text { ), and } 56 \% \text { and } 5.7 \text { (PEC). Good stability }\right. \\
\text { in PEC. Evolution of } \bullet \text { OH concentration. }\end{array}$ & [56] \\
\hline \multicolumn{5}{|l|}{ Candida parapsilosis } \\
\hline $\begin{array}{l}\text { Annular bubble reactor with an inner centered } \\
36 \mathrm{~W} \mathrm{UVB} \mathrm{lamp} \mathrm{and} \mathrm{an} \mathrm{O}_{2} / \mathrm{O}_{3} \text { inlet at the } \\
\text { bottom }\end{array}$ & $\begin{array}{l}1 \mathrm{~L} \text { of } 10 \mathrm{mg} \mathrm{L}^{-1} \text { benzophenone- } 3 \text { and } 10^{6} \mathrm{CFU} \\
\mathrm{mL}^{-1} \text { C. parapsilosis in pure water with } 0.01 \mathrm{M} \\
\mathrm{Na}_{2} \mathrm{SO}_{4}\end{array}$ & $\begin{array}{l}\mathrm{Ti} / \mathrm{TiO}_{2} \mathrm{NTs}_{\text {surrounding the UVB lamp as }} \\
\text { photoanode and DSA } \mathrm{k}_{\text {cathode. Cell voltage }} \\
=2 \mathrm{~V}, \mathrm{O}_{3} \text { input }=1.25 \times 10^{-4} \mathrm{~mol} \mathrm{~min}^{-1}\end{array}$ & $\begin{array}{l}\mathrm{PEC}+\mathrm{O}_{3} \text { process gave total cell inactivation } \\
\text { in } 45 \mathrm{~min} \text {. Little effect of the presence of the } \\
\text { fungus on benzophenone-3 degradation and } \\
\text { TOC abatement }\end{array}$ & [57] \\
\hline $\begin{array}{l}\text { Batch reactor with a three electrode system. } \\
\text { Operated with } 125 \mathrm{~W} \text { UV/vis mercury lamp }\end{array}$ & $\begin{array}{c}250 \mathrm{~mL} \text { of } 106 \mathrm{CFU} \mathrm{mL} \mathrm{mL}^{-1} \text { C. parapsilosis in acid } \\
\text { dialysate }(\mathrm{pH} 2.8 \text { ) or basic dialysate }(\mathrm{pH} 7.9) \\
\text { solutions }\end{array}$ & $\begin{array}{l}\text { Nanoporous } \mathrm{W} \mid \mathrm{WO}_{3} \text { photoanode, Pt gauze } \\
\text { cathode, and } \mathrm{Ag} \mid \mathrm{AgCl} \text { reference electrode. } \\
E_{\mathrm{an}}=+1.0 \mathrm{~V} / \mathrm{Ag} \mid \mathrm{AgCl} \text { for } 120 \mathrm{~min}\end{array}$ & $\begin{array}{l}\text { Total disinfection for PEC, } \text { PC }^{\mathrm{e}} \text {, and } \\
\text { photolysis: } 1,5 \text {, and } 10 \mathrm{~min} \text { in acid dialysate, } \\
\text { and } 5,30 \text {, and } 60 \mathrm{~min} \text { in basic dialysate. } \\
\text { Similar TOC reduction in both media: } 43 \% \\
\left.(\mathrm{PEC})>27 \%(\mathrm{PC})^{\mathrm{e}}\right)>19 \% \text { (photolysis). }\end{array}$ & [39] \\
\hline \multicolumn{5}{|l|}{ Mycobacteria } \\
\hline $\begin{array}{l}\text { Undivided three-electrode tank reactor } \\
\text { illuminated with an external } 125 \mathrm{~W} \text { UVA light }\end{array}$ & $\begin{array}{l}250 \mathrm{~mL} \text { of } 5 \times 10^{8} \mathrm{CFU} \mathrm{mL}^{-1} \mathrm{M} \text {. kansasii or } \mathrm{M} \text {. } \\
\text { avium in pure water with } 0.05 \mathrm{M} \mathrm{Na}_{2} \mathrm{SO}_{4} \text { at } \mathrm{pH} \\
6.2\end{array}$ & $\begin{array}{c}\mathrm{Ti} \mid \mathrm{TiO}_{2}-\mathrm{Ag} \mathrm{NPs} \text { photoanode, Pt gauze } \\
\text { cathode, and } \mathrm{Ag} \mid \mathrm{AgCl} \text { reference electrode. } \\
E_{\mathrm{an}}=+1.5 \mathrm{~V} / \mathrm{Ag} \mid \mathrm{AgCl} \text { for } 240 \mathrm{~min}\end{array}$ & $\begin{array}{c}\text { Inactivation and TOC removal: } \mathrm{PEC}>\mathrm{PC}^{\mathrm{e}}> \\
\text { photolysis }>\text { AO. In PEC, higher cell } \\
\text { inactivation (4.2 vs. } 3.4 \text { log units reduction) } \\
\text { and TOC abatement }(57 \% \text { vs. } 48 \% \text { ) for } M \text {. } \\
\text { kansasii. }\end{array}$ & [22] \\
\hline $\begin{array}{l}\text { Undivided three-electrode tank reactor. External } \\
\text { illumination with a } 125 \mathrm{~W} \text { UVA lamp or a } 150 \mathrm{~W} \\
\text { Xe lamp }\end{array}$ & $\begin{array}{c}250 \mathrm{~mL} \text { for UVA light or } 10 \mathrm{~mL} \text { for visible light } \\
\text { of } 7 \times 10^{4} \mathrm{CFU} \mathrm{mL}-1 \mathrm{M} \text {. }{ }^{-1} \text { megmatis in pure } \\
\text { water with } 0.05 \mathrm{M} \mathrm{Na}_{2} \mathrm{SO}_{4}\end{array}$ & 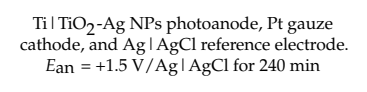 & $\begin{array}{l}\text { PEC total cell inactivation: } 3 \mathrm{~min} \text { (UVA) and } \\
>30 \mathrm{~min} \text { (visible). TOC removal: } 100 \% \text { (UVA) } \\
>37 \% \text { (visible). Negligible lixivation and } \\
\text { high stability of surface Ag deposits }\end{array}$ & [58] \\
\hline \multicolumn{5}{|l|}{ Other bacteria } \\
\hline $\begin{array}{l}\text { Stirred undivided three-electrode tank reactor } \\
\text { with an external } 125 \text { W UVC light }\end{array}$ & $\begin{array}{l}100 \mathrm{~mL} \text { of } 10^{6} \mathrm{CFU} \mathrm{mL}^{-1} \text { Pseudomonas } \\
\text { aeruginosa suspended in pure water with } 7-25 \\
\mathrm{mM} \mathrm{Na}_{2} \mathrm{SO}_{4} \text { at } \mathrm{pH} 5.9 \text { and } 25^{\circ} \mathrm{C}\end{array}$ & $\begin{array}{c}\mathrm{Ti}_{\mathrm{TiO}}-\mathrm{Ag} \text { photoanode, } \mathrm{SS} \text { cathode, and } \\
\mathrm{Ag} \mid \mathrm{AgCl} \text { reference electrode. } E_{\mathrm{an}}=+1.00 \text { or } \\
+1.70 \mathrm{~V} / \mathrm{Ag} \mid \mathrm{AgCl} \text { for } 40 \mathrm{~min}\end{array}$ & $\begin{array}{c}\text { For } \mathrm{PEC} \text {, total cell inactivation in } 25 \mathrm{mM} \\
\mathrm{Na}_{2} \mathrm{SO}_{4}(5 \mathrm{~min})<7 \mathrm{mM} \mathrm{Na} \mathrm{Na}_{2} \mathrm{SO}_{4}(30 \mathrm{~min}) \\
\text { with } \mathrm{Ti}^{\prime} \mid \mathrm{TiO}_{2}-\mathrm{Ag}(4 \%) \text { at } E_{\mathrm{an}}=+1.70 \mathrm{~V} \text {. In } 25 \\
\mathrm{mM} \mathrm{Na}_{2} \mathrm{SO}_{4} \text { with Ti } \mid \mathrm{TiO}_{2}-\mathrm{Ag}(4 \%) \text {, slower } \\
\text { total cell inactivation by } \mathrm{PC} \text { e }(40 \mathrm{~min}) \text { and } \\
\mathrm{PEC}(10 \mathrm{~min}) \text { at } E_{\mathrm{an}}=+1.00 \mathrm{~V} \text {. }\end{array}$ & [59] \\
\hline
\end{tabular}

${ }^{\text {a }}$ SS stainless steel. ${ }^{b} E_{a n}$ : anodic potential. ${ }^{c}$ AO: anodic oxidation. ${ }^{d}$ ITO: indium tin oxide. ${ }^{e}$ PC: photocatalysis. ${ }^{\text {f }}$ FTO: fluorine-doped tin oxide. ${ }^{\mathrm{g}}$ NPs: nanoparticles. ${ }^{\mathrm{h}}$ GAC: granular activated carbon. ${ }^{\mathrm{i}} j$ current density. ${ }^{\mathrm{j}}$ SPEC: solar PEC. ${ }^{\mathrm{k}}$ DSA: dimensionally stable anode. 


\section{Photoelectrocatalytic Disinfection of Microorganisms}

The disinfection power of PEC has been tested with a small number of microorganisms. While Escherichia coli has been the most typical bacterium chosen for this purpose, several studies have been performed with the fungus Candida parapsilosis and various Mycobacteria. The disinfection of water with other bacteria such as Pseudonomas aeruginosa, Legionella pneumophila, and Microcystin aeruginosa, among others using PEC has also been described. This section is devoted to explaining the characteristics of these disinfections, with selected results summarized in Table 1.

\subsection{Escherichia coli}

E. coli is one of the most common, and therefore most studied, bacteria. It is a fastgrowing Gram-negative rod shaped microorganism, with replications in $\sim 20 \mathrm{~min}$. E coli has many strains, of which some are commensal, while others are pathogenic [60]. It is a ubiquitous bacterium that survives for a long period outside the intestinal tract (its traditional home) and can replicate in soils and sediments in all climates [61]. E. coli is a fecal bacterium and thus a common pollutant in water sources. Some strains of this bacterium are resistant to antibiotics and thus pose a threat to humans. It has been found in diverse water sources, such as drinking water, surface water, municipal wastewater, and so on. Based on these facts, the removal of E. coli from water is needed to ensure human health.

While PEC has been applied for the removal of a wide range of organic pollutants, it has also found application in the removal of microorganism pollutants such as E. coli. Early works on the application of PEC for the inactivation of this bacterium were based on the use of $\mathrm{TiO}_{2}$ deposits onto Ti as a photoanode with irradiation with a UVA light [50,62-64]. Philippidis et al. [50] carried out the photoelectrochemical disinfection of $500 \mathrm{~mL}$ of $10^{3} \mathrm{CFU} \mathrm{mL}{ }^{-1}$ E. coli in $0.10 \mathrm{M} \mathrm{Na}_{2} \mathrm{SO}_{4}$ at $\mathrm{pH} 5.6$ and $25^{\circ} \mathrm{C}$. The reaction took place in a stirred, undivided three-electrode cell, with $\mathrm{TiO}_{2} \mathrm{P}-25$ deposited onto Ti substrates upon an inner $9 \mathrm{~W}$ UVA light at $E_{\mathrm{an}}=+1.0 \mathrm{~V} / \mathrm{Ag} \mid \mathrm{AgCl}$. The authors reported an $11 \%$ inactivation with $\mathrm{AO}$ in $120 \mathrm{~min}$, and an overall disinfection after $105 \mathrm{~min}$ of PC and $60 \mathrm{~min}$ of PEC, demonstrating the superior performance of PEC over the individual treatments. The authors established a small effect for the inactivation efficiency, between $10^{3}$ and $10^{7} \mathrm{CFU} \mathrm{mL}{ }^{-1}$ of cells, and demonstrated that a composite $\mathrm{Ti}_{\mathrm{I}} \mathrm{TiO}_{2}-\mathrm{Pt}$ photoanode favored the disinfection process (see Table 1).

The deposition of sol-gel $\mathrm{TiO}_{2}$ has been carried out on Al [23], ITO [51,54,64], and FTO [52] substrates. Domínguez-Espíndola et al. [23] prepared $\mathrm{Al} \mid \mathrm{TiO}_{2}$ and $\mathrm{Al} \mid \mathrm{TiO}_{2}-\mathrm{Ag}$ photoanodes that were introduced into a cell similar to that of Figure $3 \mathrm{~d}$ with illumination of $4 \mathrm{~W}$ UVA light containing $50 \mathrm{~mL}$ of $1.6 \times 10^{9} \mathrm{CFU} \mathrm{mL}{ }^{-1}$ fecal coliforms $\left(1.2 \times 10^{6} \mathrm{CFU}\right.$ $\mathrm{mL}^{-1}$ E. coli) in real urban wastewater at $\mathrm{pH}$ 7.9. The $\mathrm{Al} / \mathrm{TiO}_{2}-\mathrm{Ag}$ photoanode performed better than the $\mathrm{Al} / \mathrm{TiO}_{2}$ one at cell voltages of $0.5-1.5 \mathrm{~V}$. Total disinfection was achieved in $3 \mathrm{~min}$ for the former, vs. $6 \mathrm{~min}$ for the latter. Much slower inactivation was found with AO without illumination, as expected from the higher disinfectant power of PEC with its greater ROS production from the generation of $\mathrm{e}_{\mathrm{CB}}{ }^{-} / \mathrm{h}_{\mathrm{VB}}{ }^{+}$by Reaction (1) (see Table 1). Note that aluminum substrates are not recommended, because exposure to the solution may induce electrodissolution of the aluminum substrate. Generally, these kinds of substrate should be avoided to prevent undesired accelerated degradation of the photoelectrode. $\mathrm{Li}$ et al. [64] reported from $99.90 \%$ to $100 \%$ inactivation of E. coli by PEC in the presence of $1.0 \mathrm{mM} \mathrm{Br}{ }^{-}$, which yielded $\mathrm{Br}^{\bullet-} / \mathrm{Br}_{2}{ }^{\bullet-}$ as disinfectants in less than $2 \mathrm{~s}$ from a bacterial concentration of $9 \times 10^{6} \mathrm{CFU} \mathrm{mL}^{-1}$ in $0.1 \mathrm{M} \mathrm{NaNO}_{3}$. However, halogen oxidants may be susceptible to yielding disinfection by-products, where bromine containing organics have been reported to be more toxic than organochlorine species [65]. A unique setup with flow at small rate through a three-electrode reactor with an $\mathrm{ITO} I \mathrm{TiO}_{2}$ photoanode submitted to an anodic potential $\left(E_{\mathrm{an}}\right)$ of $+0.3 \mathrm{~V} / \mathrm{Ag} \mid \mathrm{AgCl}$ and illuminated with an external UV-LED light of $365 \mathrm{~nm}$ was used. The PEC treatment without $\mathrm{Br}^{-}$was less potent, giving $100 \%$ inactivation after $300 \mathrm{~s}$. This report reveals that the introduction of other non-conventional radicals as oxidizing agents drastically enhances the disinfection capacity of PEC systems, 
by oxidation with ROS formed from Reactions (2) and (3). Further works by this team under the same conditions [51] disclosed a slower disinfection with $1.0 \mathrm{mM} \mathrm{Cl}^{-}$than with $1.0 \mathrm{mM} \mathrm{Br}^{-}$for PC and PEC, requiring $1.57 \mathrm{~s}$ with $\mathrm{Br}^{-}$and $23.3 \mathrm{~s}$ with $\mathrm{Cl}^{-}$for total cell inactivation. A longer time of $311 \mathrm{~s}$ was needed without these ions. The bactericide action of $\mathrm{Br}^{\bullet-} / \mathrm{Br}_{2}{ }^{\bullet-}$ was similar at $\mathrm{pH}$ 5.5-9.0 and between 0.05 and $2 \mathrm{mM} \mathrm{Br}^{-}$(see Table 1). Liu et al. [52] explored the use of a FTO I (1 111 ) rutile $\mathrm{TiO}_{2}$ photoanode with an undivided three-electrode tank reactor illuminated with an external $150 \mathrm{~W}$ Xe lamp that was filtered to obtain UV and visible light. In this batch system, $45 \mathrm{~mL}$ of $10^{7} \mathrm{CFU} \mathrm{mL}{ }^{-1}$ bacteria in $0.10 \mathrm{M} \mathrm{NaNO}_{3}$ was treated by $\mathrm{AO}$ and PEC at $E_{\mathrm{an}}=+0.4 \mathrm{~V} / \mathrm{Ag} \mid \mathrm{AgCl}$. PEC was always superior to $\mathrm{PC}$, and much slower inactivation was obtained by $\mathrm{AO}$ and direct photolysis. The more energetic photons of UV yielded a higher disinfection rate that those of visible light. It was also found that direct solar illumination was much more effective for PEC due to its greater UV intensity (see Table 1). It is important to remark that UVC sources can also attain disinfection given certain doses of high-energy photons that can damage the genetic material of bacteria [66]. Thus, blank experiments are required to evaluate the bacteria inactivation of the light sources employed.

The excellent results obtained for the PEC treatment of $E$. coli have been confirmed in many works with $\mathrm{Ti} / \mathrm{TiO}_{2}$ NTs photoanodes prepared by the anodization of a titanium sheet $[28,30,47,53,54,67-69]$. In a first work, Baram et al. [67] used an undivided threeelectrode tank reactor connected to an external $30 \mathrm{~W}$ UVA lamp to disinfect a solution containing about $10^{6}-10^{7} \mathrm{CFU} \mathrm{mL} \mathrm{m}^{-1}$ of E. coli bacteria (strain CN13) and $0.01 \% \mathrm{NaCl}$ al pH 5.2 and $E_{\text {an }}$ within the range of +1 to $+18 \mathrm{~V} / \mathrm{SCE}$ for 3 to $6 \mathrm{~h}$. The number of bacteria removed increased with increasing applied voltage up to $15 \mathrm{~V}$, and over $99 \%$ of the E. coli cells were inactivated after $6 \mathrm{~h}$ at $15 \mathrm{~V}$. Two years later, this research group [53] prepared another morphology of $\mathrm{Ti} / \mathrm{TiO}_{2} \mathrm{NT}$ from a fluoride ion containing an electrolyte (as earlier reported by Macak et al. [70]) that allowed a better application of PEC at much lower $E_{\text {an }}$ between +0.2 and $5.0 \mathrm{~V} / \mathrm{SCE}$ in the same system. Complete inactivation of the bacteria was achieved for decreasing times of 30,20,15, and $10 \mathrm{~min}$ at increasing $E_{\mathrm{an}}$ values of $+0.2,+1.0,+2.0$, and $+3.0 \mathrm{~V} / \mathrm{SCE}$, respectively; clearly improving the PC treatment (see Table 1). This study suggests that the inactivation of E. coli (and other microorganism) depends on the morphology of the semiconductor used. Pablos et al. [54] reported the PEC treatment of $15 \mathrm{~mL}$ of $10^{6} \mathrm{CFU} \mathrm{mL}{ }^{-1}$ E. coli in $\frac{1}{4}$ strength Ringers solution at 25 ${ }^{\circ} \mathrm{C}$ with a stirred undivided three-electrode tank reactor, with air bubbling to enhance the $\mathrm{O}_{2}{ }^{\bullet-}$ generation from Reaction (3). This was illuminated with an external $450 \mathrm{~W}$ Xe lamp to provide UV-Vis light and was cutoff at $\lambda<420 \mathrm{~nm}$ for visible light. Two kinds of $\mathrm{Ti} I \mathrm{TiO}_{2} \mathrm{NTs}$ photoanode were used, without and with $\mathrm{N}$ doping, which did not yield any disinfection with $\mathrm{AO}$. Total disinfection was attained more rapidly with the $\mathrm{Ti} I \mathrm{~N}-\mathrm{TiO}_{2}$ NTs photoanode than the $\mathrm{Ti} / \mathrm{TiO}_{2} \mathrm{NTs}$ one upon UV-Vis illumination in PEC, with a lower efficiency, as expected, with visible light (see Table 1). These findings indicate that the doping of $\mathrm{TiO}_{2}$ with non-metal atoms can upgrade the disinfection power of a PEC system. The influence of the cathode on the performance of the PEC process was recently examined by Salmerón et al. [30]. The photoelectrocatalytic reactor of Figure 3d with a $\mathrm{Ti}_{\text {I }} \mathrm{TiO}_{2} \mathrm{NTs}$ photoanode and either a Ti I Pt or carbon felt cathode was used for the treatment of $190 \mathrm{~mL}$ of $10^{6} \mathrm{CFU} \mathrm{mL} \mathrm{m}^{-1}$ E. coli in surface water at $\mathrm{pH}$ 7.4. The carbon-felt cathode produced the bactericide $\mathrm{H}_{2} \mathrm{O}_{2}$ from the two-electron reduction of the $\mathrm{O}_{2}$ dissolved in the water, and apart from the ROS produced from Reactions (2) and (3), active chlorine was generated from the anodic oxidation of $\mathrm{Cl}^{-}$present in the medium. These authors confirmed the formation of both kinds of oxidants and the prevalence of PEC over PC and AO for both cathodes (see Table 1). Figure 4a highlights that after supplying a cell voltage of $1 \mathrm{~V}$ for $120 \mathrm{~min}$, the Ti/Pt cell led to increasing 0.04, 1.00, and $2.40 \mathrm{log}$ unit cell reductions for $\mathrm{AO}, \mathrm{PC}$, and PEC, respectively. In the Ti/carbon-felt cell, slightly greater decays of 0.10 , 1.15 , and $2.90 \log$ units were obtained by the additional action of the generated $\mathrm{H}_{2} \mathrm{O}_{2}$, as shown in Figure $4 \mathrm{~b}$. An enhancement of the inactivation process can be observed in the presence of organic micropollutants (OMP), due to the toxic byproducts that they produce. 
This point was confirmed by adding high concentrations $(5 \mathrm{mM})$ of methanol and acetate as hole acceptors, which are directly oxidized instead of the molecules of the cell wall. Figure $4 \mathrm{c}$ depicts a drastic decay of $5 \mathrm{log}$ units in the presence of both organics, because of the rapid indirect inactivation of the bacterium with their byproducts. These findings give evidence of the influence of the organic composition of real wastewaters for explaining the direct and/or indirect inactivation of bacteria by the generated disinfectants or organic byproducts, respectively.

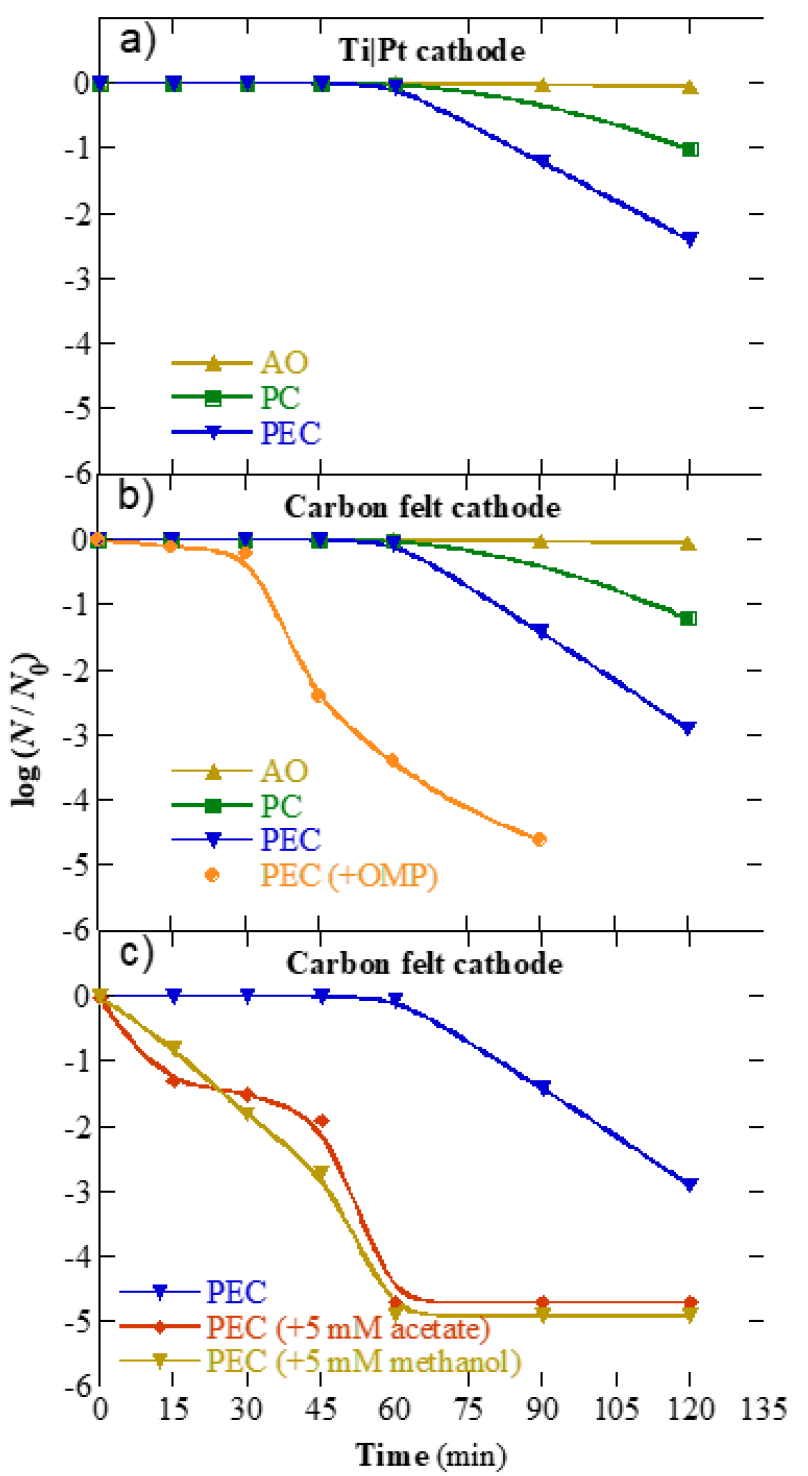

Figure 4. Inactivation of $10^{6} \mathrm{CFU} \mathrm{mL}^{-1}$ E. coli in $190 \mathrm{~mL}$ of surface water with the addition of organic micropollutants (OMP) at $\mathrm{pH} 7.4$ using the system of Figure $3 \mathrm{~d}$ with $\mathrm{Ti} \mid \mathrm{TiO}_{2}-\mathrm{NTs}$ acting as anode, photocatalyst, or photoanode for AO, PC, or PEC, respectively. The photo-assisted processes were carried out with an $18 \mathrm{~W}$ UVA light. A cell voltage of $1.0 \mathrm{~V}$ was applied to the AO and PEC trials. Comparative assays using: (a) Ti I Pt or (b), (c) carbon felt cathode. In (c), the suspension was polluted with $5 \mathrm{mM}$ methanol or acetate as hole acceptor. Adapted from [30].

Other PEC systems have been developed with different $\mathrm{TiO}_{2}$ arrangements. Figure 5 presents a curious system, in which $\mathrm{TiO}_{2}$ supported by granular activated carbon (GAC) was placed in a central basket of a cell, like that in Figure $3 c$, with a $100 \mathrm{~cm}^{2} \mathrm{Pt} \mid \mathrm{RuO}_{2}$ anode and a $100 \mathrm{~cm}^{2}$ SS cathode and irradiated with an inner $6 \mathrm{~W}$ UVA light to treat $10^{3} \mathrm{CFU} \mathrm{mL} \mathrm{m}^{-1}$ E. coli in synthetic fish farm wastewater at $\mathrm{pH} 6.2$ [71]. Figure 5a shows 
that the PC process with $\mathrm{GAC}-\mathrm{TiO}_{2}$ yielded $2.65 \mathrm{log}$ unit decay after $120 \mathrm{~min}$ and was much more rapid than direct photolysis, GAC alone, and PC with GAC; corroborating the photoactivation of $\mathrm{TiO}_{2}$ onto GAC. This was more clearly evidenced when PEC with GAC- $\mathrm{TiO}_{2}$ was performed. Figure $5 \mathrm{~b}$ discloses the poor inactivation contribution of $\mathrm{AO}$ vs. PEC with $\mathrm{GAC}-\mathrm{TiO}_{2}$ at $j=0.03 \mathrm{~mA} \mathrm{~cm}{ }^{-2}$, with the need of raising $j$ up to $0.10 \mathrm{~mA}$ $\mathrm{cm}^{-2}$ to attain overall disinfection for PEC with $\mathrm{GAC}^{-\mathrm{TiO}_{2}}$ (see also Table 1). These results suggested that $\mathrm{GAC}-\mathrm{TiO}_{2}$ behaves as a bipolar electrode upon photoexcitation, with a large production of ${ }^{\bullet} \mathrm{OH}$ from Reaction (2) as the main disinfectant. The close relationship between the disinfection ability of this procedure and the rate of ${ }^{\bullet} \mathrm{OH}$ generation can be inferred by comparing Figure $5 b, c$.
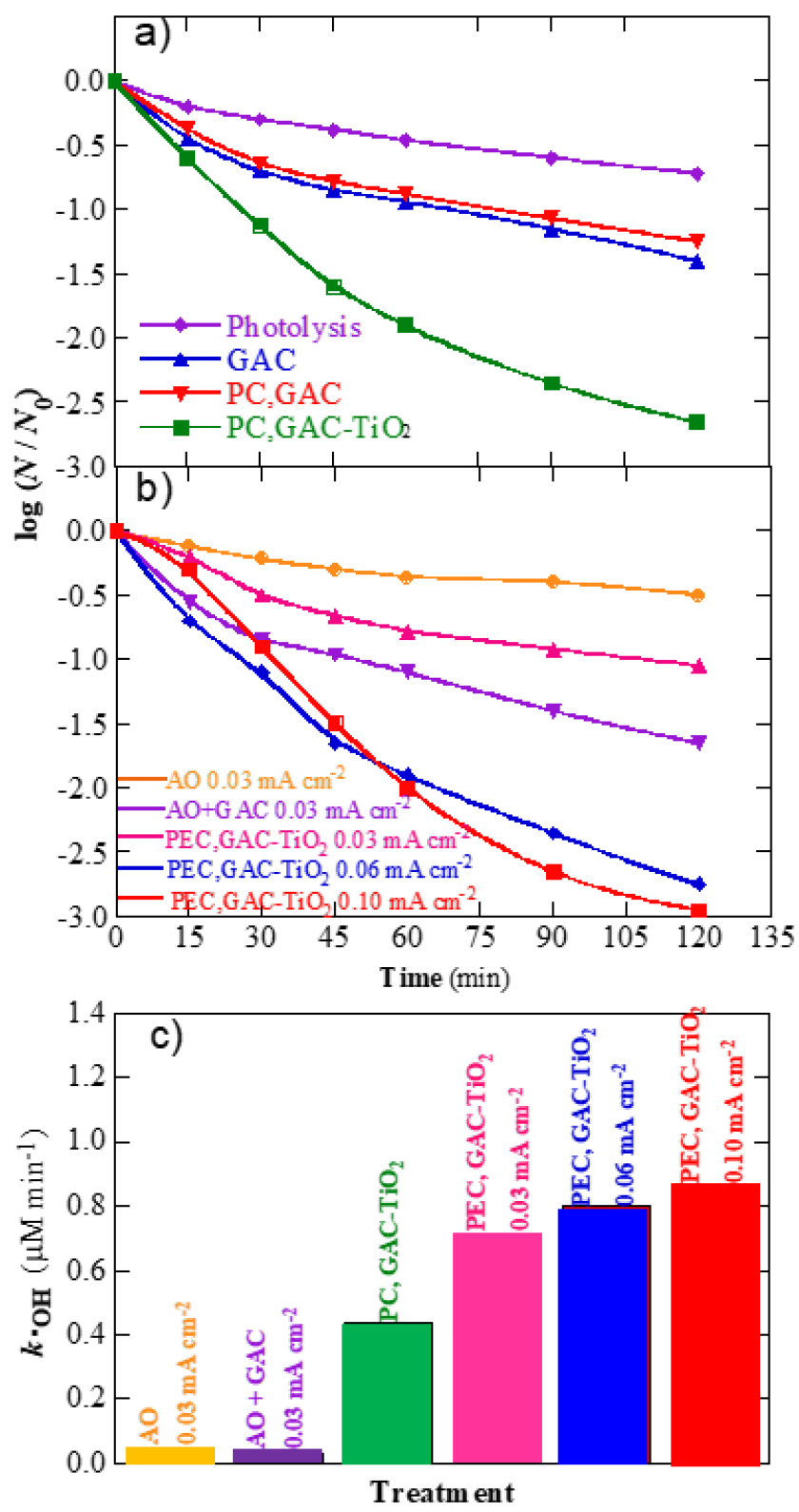

Figure 5. Time course of the inactivation of $10^{3} \mathrm{CFU} \mathrm{mL}{ }^{-1}$ E. coli in synthetic fish farm wastewater at $\mathrm{pH}$ 6.2, using a cell similar to that of Figure 3c, with air bubbling containing a $\mathrm{Pt} \mathrm{I} \mathrm{RuO}_{2}$ anode and a SS cathode, both of $100 \mathrm{~cm}^{2}$ area, with an inner $6 \mathrm{~W}$ UVA lamp and a central basket containing $\mathrm{TiO}_{2}$ supported by granular activated carbon (GAC) as bipolar electrode $\left(\mathrm{GAC}-\mathrm{TiO}_{2}\right)$. Comparison of (a) photolytic and photocatalytic treatments and (b) AO and PEC processes at different current densities (j). (c) Rate of hydroxyl radical generation for different treatments determined from methanol oxidation to formaldehyde. Adapted from [71]. 
Nie et al. [55] prepared different composites of $\mathrm{N}$-doped carbonaceous $\mid \mathrm{TiO}_{2}$ photoanodes by a hydrothermal technique at 120,150 , and $180^{\circ} \mathrm{C}$. These photoanodes were put in a stirred, undivided three-electrode tank reactor irradiated with visible light provided by a $300 \mathrm{~W}$ Xe lamp with filters cutting-off $\lambda<420 \mathrm{~nm}$ and aiming to disinfect $50 \mathrm{~mL}$ of $10^{7}$ CFU mL ${ }^{-1}$ E. coli (strain $\mathrm{K} 12$ ) in $0.2 \mathrm{M} \mathrm{NaNO}_{3}$. Figure 6a depicts a weak cell inactivation by photolysis and $\mathrm{AO}$ at $E_{\mathrm{an}}=+1.0 \mathrm{~V} / \mathrm{Ag} \mid \mathrm{AgCl}$ for the composite prepared at $150{ }^{\circ} \mathrm{C}$, whereas the photoactivation of the $\mathrm{TiO}_{2}$ component with $\mathrm{ROS}$ generation yielded total inactivation after $90 \mathrm{~min}$ of PEC and $40 \mathrm{~min}$ of PEC at the same $E_{\mathrm{an}}$ value. Figure $6 \mathrm{~b}$ shows that the cell inactivation was enhanced at lower hydrothermal temperature, and $30 \mathrm{~min}$ were required for total disinfection with the composite prepared at $120^{\circ} \mathrm{C}$ (see Table 1). This phenomenon was ascribed to the larger inclusion of synthesized $\mathrm{N}$-doped carbonaceous into micron-sized $\mathrm{TiO}_{2}$ spheres at $120^{\circ} \mathrm{C}$, which could enhance the absorption of the visible light.

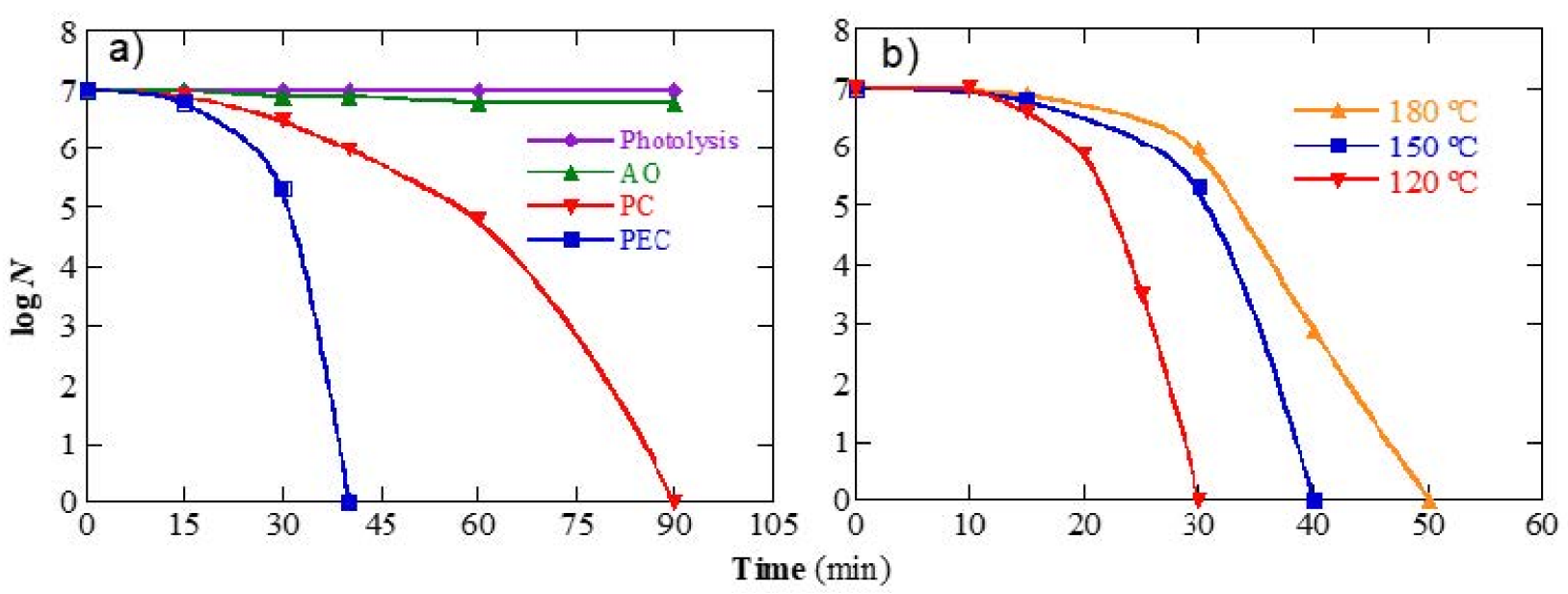

Figure 6. (a) Time course of log units of bacteria for $50 \mathrm{~mL}$ of $10^{7} \mathrm{CFU} \mathrm{mL}{ }^{-1}$ E. coli aqueous suspensions with $0.2 \mathrm{M} \mathrm{NaNO}_{3}$ treated with a stirred undivided three-electrode tank reactor by means of photolysis, AO, PC, and PEC processes, using a composite $\mathrm{N}$-doped carbonaceous $\mid \mathrm{TiO}_{2}$ photoanode prepared at $150^{\circ} \mathrm{C}$, a Pt cathode, and an $\mathrm{Ag} \mid \mathrm{AgCl}$ reference electrode. For the photo-assisted processes, a $300 \mathrm{~W}$ Xe lamp with filters cutting-off $\lambda<420 \mathrm{~nm}$ (visible light) was used. For AO and $\mathrm{PEC}$, and $E_{\mathrm{an}}=+1.0 \mathrm{~V} / \mathrm{Ag} \mid \mathrm{AgCl}$ was applied. (b) PEC inactivation curves for composite photoanodes prepared at different hydrothermal temperatures. Adapted from [55].

Rahmawati et al. [72] used a divided system, similar to Figure 3b, for the treatment of $100 \mathrm{~mL}$ of $10^{5} \mathrm{CFU} \mathrm{mL} \mathrm{m}^{-1} \mathrm{E}$. coli in pure water filled into the anodic compartment. The cathodic compartment contained $100 \mathrm{~mL}$ of $0.1 \mathrm{M} \mathrm{KCl}$ and a graphite rod cathode. Two composites of $\mathrm{Ag}-\mathrm{TiO}_{2}$ I graphite and $\mathrm{Cu}-\mathrm{TiO}_{2}$ I graphite were prepared as photoanodes and illuminated with a $6 \mathrm{~W}$ UVC light in the anodic compartment. Figure 7a,b shows the percentage of cell inactivation by different processes for both photoanodes, respectively, with the application of a cell voltage of $3 \mathrm{~V}$ for $30 \mathrm{~min}$ for AO and PEC. The percent of bacteria population that remained inactivated after 24 and $48 \mathrm{~h}$ is given to assess the replication ability of the treated cells. The same tendency can be observed in both figures. At the end of the treatment with $\mathrm{Ag}-\mathrm{TiO}_{2}$ I graphite, the percentage cell inactivation increased in the sequence: photolysis $(38 \%)<\mathrm{PC}(80 \%)<\mathrm{AO}(84 \%)<\mathrm{PEC}(90 \%)$, whereas for $\mathrm{Cu}-\mathrm{TiO}_{2}$ I graphite, slightly lower values were obtained: photolysis $(38 \%)<\mathrm{PC}(77 \%)$ $<\mathrm{AO}(82 \%)<$ PEC $(87 \%)$. The inactivation increased strongly after $48 \mathrm{~h}$ of photolysis $(90 \%)$ and slightly after the other treatments in the case of $\mathrm{Ag}-\mathrm{TiO}_{2}$ I graphite. For $\mathrm{Cu}-$ $\mathrm{TiO}_{2}$ I graphite, only an enhancement of the cell population was found for $\mathrm{AO}$, whose inactivation dropped to $61 \%$ in $48 \mathrm{~h}$. These findings demonstrate the high ability for disinfection of PEC that can be prolonged and even increased in further days after its application. Since the $\mathrm{Ag}-\mathrm{TiO}_{2}$ I graphite composite presented better performance, a further work by these authors [49] was centered on its use in the same system with direct sunlight, 
revealing an unexpected behavior, since greater cell inactivation was achieved by AO than by SPEC after 30 min of treatment. This was explained by the existence of auto-oxidation of the doping Ag in the anode in both processes, which produced a different inactivation activity. This instability makes it evident that divided reactors are not appropriated for PEC because they require high cell voltages due to the voltage penalty of the separator between the two compartments that can oxidize the anode.
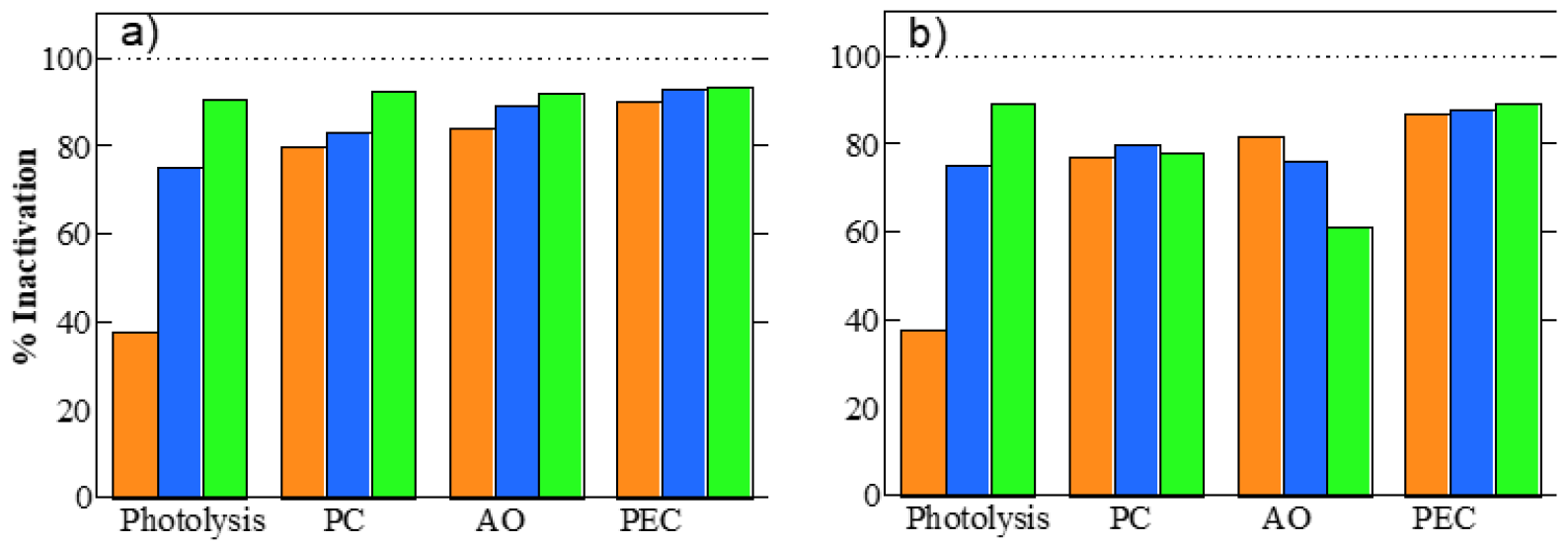

Treament

Figure 7. Percentage of inactivation of E. coli with photolysis, PC, AO, and PEC for $100 \mathrm{~mL}$ of $10^{5} \mathrm{CFU} \mathrm{mL}^{-1}$ bacteria in pure water filling the anodic compartment of a divided cell similar to that of Figure $3 b$, with the same cathodic compartment. Anode: (a) $\mathrm{Ag}-\mathrm{TiO}_{2}$ I graphite and (b) $\mathrm{Cu}-\mathrm{TiO}_{2}$ I graphite. The anodic compartment was irradiated with an external 6 W UVC light. A cell voltage of $3 \mathrm{~V}$ was applied in AO and PEC. All trials were carried out for 30 min and the bacteria population was also determined after 24 and $48 \mathrm{~h}$ of each treatment. Adapted from [72].

Several works have reported photoanodes with materials having a lower $E_{\mathrm{g}}$ value than $\mathrm{TiO}_{2}$, aiming to enhance the cell inactivation by visible light. FTO $\mid \mathrm{CuO}$ or FTO $\mid \mathrm{CuO}$ nanoroads (NRs) [38], $\mathrm{Ti}\left|\mathrm{TiO}_{2}-\mathrm{Ag}\right| \mathrm{SnO}_{2}-\mathrm{Sb}$ [73], FTO $|\mathrm{ZnO}| \mid \mathrm{CuI}$ [74], and $\mathrm{Ti} \mid \mathrm{MoS}_{2}$ [56] were investigated. For instance, Eswar et al. [38] studied the simultaneous removal of 25 $\mathrm{mg} \mathrm{L}^{-1}$ tetracycline and $10^{9} \mathrm{CFU} \mathrm{mL} \mathrm{m}^{-1} \mathrm{E}$. coli in pure water at $15^{\circ} \mathrm{C}$ with a photoreactor similar to Figure $3 \mathrm{~d}$ and external illumination with a $400 \mathrm{~W} \mathrm{UV}-$ Vis light that was filtered to provide visible light with $\lambda_{\max }=510 \mathrm{~nm}$. By using a FTO I CuO photoanode and applying a cell voltage of $3 \mathrm{~V}$ in the electrolytic assays, an increasing cell reduction of 1.7, 6.0, 6.9, and 9.0 (total) log units was determined for photolysis, AO, PC, and PEC at $25 \mathrm{~min}$; showing the good disinfection ability of the PEC system under these conditions. Tetracycline was completely removed in 60 and $80 \mathrm{~min}$ in the presence and absence of $E$. coli. The smaller time needed in the former case was ascribed to the influx of the drug into the cell of the E. coli when they were combined. Better performance was obtained with the FTO I CuO photoanode as compared to the FTO I CuO NRs one in PEC, which presented high stability and reusability. These authors found that $\mathrm{e}_{\mathrm{CB}}{ }^{-}$and $\mathrm{O}_{2}{ }^{--}$were the main disinfectants produced (see Table 1). Thus suggesting that both charge carriers may be involved in the inactivation mechanism. Further research is required to clarify the involvement of these species. He et al. [73] used a reactor similar to Figure $3 d$, with a $\mathrm{Ti}\left|\mathrm{TiO}_{2}-\mathrm{Ag}\right| \mathrm{SnO}_{2}-\mathrm{Sb}$ photoanode illuminated with a $250 \mathrm{~W}$ Xe light to treat a mixture of $1.2 \mathrm{mg} \mathrm{L}^{-1} 17 \alpha$-ethinylestradiol and $10^{9} \mathrm{CFU} \mathrm{mL}^{-1}$ E. coli in $100 \mathrm{mM} \mathrm{Na}_{2} \mathrm{SO}_{4}$ at $\mathrm{pH} 4.0$-and $20{ }^{\circ} \mathrm{C}$. Photolysis and PC yielded $3 \%$ and $19.0 \%$ of $17 \alpha$-ethinylestradiol, and 4.4 and $4.7 \mathrm{log}$ units of cell inactivation, respectively. At $j=40 \mathrm{~mA} \mathrm{~cm}^{-2}$ for $60 \mathrm{~min}$, AO only improved the degradation of the organic pollutant to $34 \%$, whereas the most powerful PEC enhanced substantially this degradation to $56 \%$, but only allowed a discrete reduction of $5.7 \log$ units of E. coli (see Table 1). This material then presented a low disinfection ability in PEC, although with a good stability. On the other hand, SPEC was applied by Zhang et al. [56], with a stirred undivided three-electrode quartz reactor with a Ti I $\mathrm{MoS}_{2}$ photoanode directly 
illuminated by sunlight. A volume of $100 \mathrm{~mL}$ of $10^{5}-10^{7} \mathrm{CFU} \mathrm{mL} \mathrm{mL}^{-1}$ E. coli in $\mathrm{NaCl}$ was disinfected in this system under different experimental conditions (see Table 1). Figure 8a shows a very low inactivation of this solution under solar photolysis and $\mathrm{AO}$ with $0.10 \mathrm{M}$ $\mathrm{NaCl}$ at $E_{\mathrm{an}}=+0.5 \mathrm{~V} / \mathrm{Ag} \mid \mathrm{AgCl}$, whereas the SPEC became very efficient, yielding total inactivation in $120 \mathrm{~min}$, with the latter conditions. The trial and error results of Figure $8 \mathrm{~b}-\mathrm{e}$ allowed concluding that the best operating conditions were attained operating at $E_{\text {an }}$ $=+0.5 \mathrm{~V} / \mathrm{Ag} \mid \mathrm{AgCl}, 0.10 \mathrm{M} \mathrm{NaCl}$, and $10^{6} \mathrm{CFU} \mathrm{mL}^{-1}$ of bacterium, as well as purging the solution with $\mathrm{O}_{2}$ to accelerate the production of $\mathrm{O}_{2}{ }^{\bullet-}$ by Reaction (3). The efforts that made by the authors to assess the disinfection action of the generated oxidizing agents using specific scavengers are notable. Figure $8 \mathrm{f}$ reveals that the loss of inactivation from

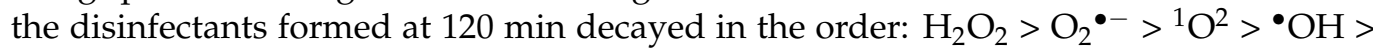
$\mathrm{e}_{\mathrm{CB}}{ }^{-}$, alongside a very small contribution of $\mathrm{h}_{\mathrm{VB}}{ }^{+}$. This indicates the complex formation of ROS needed to inactivate the cell and the preponderant role of $\mathrm{e}_{\mathrm{CB}}{ }^{-}$over $\mathrm{h}_{\mathrm{VB}}{ }^{+}$, despite its extraction from the photoanode to pass to the cathode.
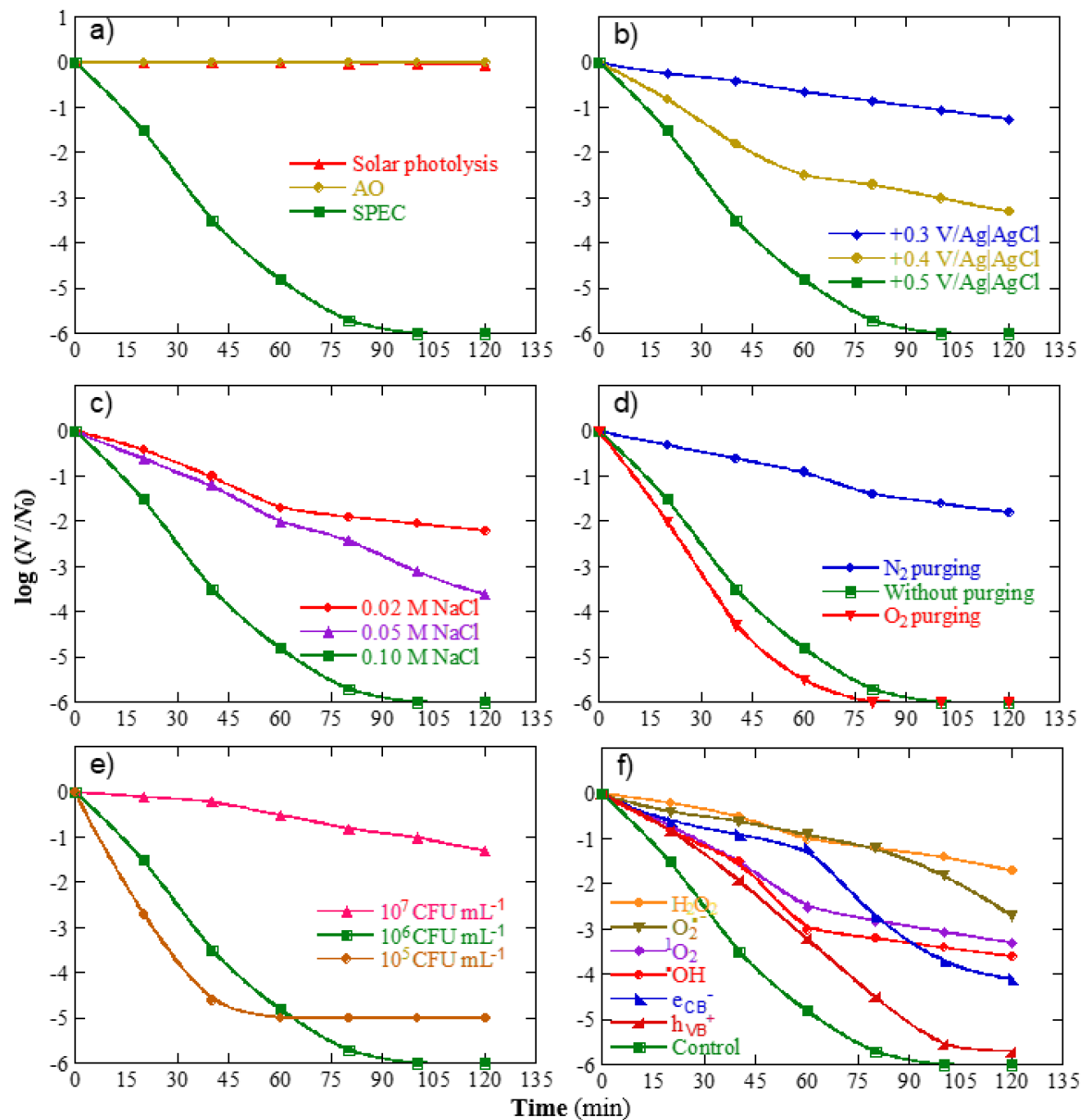

Figure 8. Change of inactivation of $10^{6} \mathrm{CFU} \mathrm{mL} \mathrm{m}^{-1}$ E. coli with time by SPEC for $100 \mathrm{~mL}$ of bacteria suspension in $0.10 \mathrm{M}$ $\mathrm{NaCl}$ using a stirred undivided three-electrode quartz reactor equipped with a Ti I MoS 2 photoanode, a Pt wire cathode, and an $\mathrm{Ag} \mid \mathrm{AgCl}$ reference electrode by applying an $E_{\mathrm{an}}=+0.5 \mathrm{~V} / \mathrm{Ag} \mid \mathrm{AgCl}$ upon solar irradiation. (a) Comparison of this control assay with solar photolysis and AO under analogous electrolytic conditions Effect over the control assay of: (b) $E_{\text {an }}$ (c) $\mathrm{NaCl}$ concentration, (d) the solution purging with $\mathrm{N}_{2}$ or $\mathrm{O}_{2},(\mathbf{e})$ the initial bacteria population, and (f) after removal of single generated disinfectants from selected scavengers. Adapted from [56]. 


\subsection{Candida parapsilosis}

Candida parapsilosis, though commensal to the skin, is an emerging fungal species of yeast of huge health concern, especially in the hospital environment, and coming from excrement or from human skin $[75,76]$. It forms biofilms, and patients with any form of medical implant, such as a catheter, are at high risk of infection. Biofilms of this yeast have been found in washing machines, dishwashers, and swimming pool water $[77,78]$.

Zanoni's group studied extensively the inactivation of $C$. parapsilosis by PEC with different systems, photoanodes, and light sources. In the former work of Pires et al. [79], an undivided three-electrode tank reactor filled with fungal solution or biofilms in $0.05 \mathrm{M} \mathrm{Na}_{2} \mathrm{SO}_{4}$ at $\mathrm{pH} 6$ and $20^{\circ} \mathrm{C}$ were disinfected with $\mathrm{Ti} / \mathrm{TiO}_{2}$ or Ti $/ \mathrm{TiO}_{2}-\mathrm{Ag}$ photoanodes at $E_{\mathrm{an}}=+1.5 \mathrm{~V} / \mathrm{Ag} \mid \mathrm{AgCl}$ upon an external $125 \mathrm{~W}$ UVA illumination. As expected, the PEC process was prevalent over photolysis and PC, and promoted the overall inactivation of $10^{6} \mathrm{CFU} \mathrm{mL} \mathrm{mL}^{-1}$ cells in $180 \mathrm{~s}$ with the $\mathrm{Ti} / \mathrm{TiO}_{2}$ photoanode. The disinfection performance was not practically affected when alternately the $\mathrm{Ti} / \mathrm{TiO}_{2}-\mathrm{Ag}$ photoanode was used, which is rather surprising, because the latter material presents a higher inactivation power for E. coli [23]. The authors also reported the good ability of PEC with $\mathrm{Ti} / \mathrm{TiO}_{2}$ to inactivate $10^{6} \mathrm{CFU} \mathrm{mL}{ }^{-1}$ cells as fungal biofilms on PTFE, silicone, and polyvinyl chloride in 60, 10, and $60 \mathrm{~min}$, respectively, with $91 \%, 91 \%$, and $71 \%$ mineralization. Further work by Kim et al. [57] was carried out with a $\mathrm{Ti}^{\prime} \mathrm{TiO}_{2} \mathrm{NTs}$ photoanode surrounding a $36 \mathrm{~W}$ UVB light and bubbling $\mathrm{O}_{3}$ through an annular reactor to enhance the disinfection power of the system.

As can be seen in Table 1, they treated $1 \mathrm{~L}$ of $10 \mathrm{mg} \mathrm{L}^{-1}$ benzophenone- 3 and $10^{6}$ CFU mL ${ }^{-1}$ C. parapsilosis in $0.01 \mathrm{M} \mathrm{Na}_{2} \mathrm{SO}_{4}$ with an input flow rate of $\mathrm{O}_{3}$ of $1.25 \times 10^{-4}$ mol $\mathrm{min}^{-1}$, and obtained total cell inactivation in $45 \mathrm{~min}$, by applying a cell voltage of 2 V. These results were worse than those obtained in the earlier work of Pires et al. [79], suggesting that inactivation was mainly due to the ROS originated from PEC, which mainly depended on the $E_{\text {an }}$ value and light intensity. Nevertheless, the PEC process with $\mathrm{O}_{3}$ overcome the process without this oxidant, allowing a $100 \%$ degradation of benzophenone3 in $25 \mathrm{~min}$ and $80 \%$ TOC abatement in $90 \mathrm{~min}$. Owing to the prevalence of $C$. parapsilosis in hemodialysis infection, Souza et al. $[39,80]$ evaluated the inactivation of this fungus in synthetic acid ( $\mathrm{pH}$ 2.8) and basic ( $\mathrm{pH}$ 7.9) dialysate solutions, mimicking those used in hospitals. A nanoporous $\mathrm{W} I \mathrm{WO}_{3}$ electrode prepared by $\mathrm{W}$ anodization was subjected to $125 \mathrm{~W}$ UV-Vis or visible irradiation in an air-stirred undivided three-electrode tank reactor. The PEC assays were made with $250 \mathrm{~mL}$ of $10^{6} \mathrm{CFU} \mathrm{mL}{ }^{-1}$ C. parapsilosis in each medium at $E_{\mathrm{an}}=+1.0 \mathrm{~V} / \mathrm{Ag} \mid \mathrm{AgCl}$ for $120 \mathrm{~min}$. Figure 9a,b evidence that a greater photocurrent density was generated in the acid dialysate compared with the basic one, and was much superior with UV-Vis than visible light. Operating with the former irradiation, overall inactivation took place at 10,5, and $1 \mathrm{~min}$, and 60, 30, and $5 \mathrm{~min}$ for photolysis, PC, and PEC, using the acid and basic dialysate, respectively (see Figure 9c,d). Despite the greater disinfection power in acid dialysate, Figure $9 \mathrm{e}, \mathrm{f}$ shows similar increasing TOC abatements of $19 \%, 27 \%$, and $43 \%$ found for such treatments regardless of the medium tested (see also Table 1). These findings encourage deeper studies of PEC as a promising technology for the disinfection of real dialysates. 

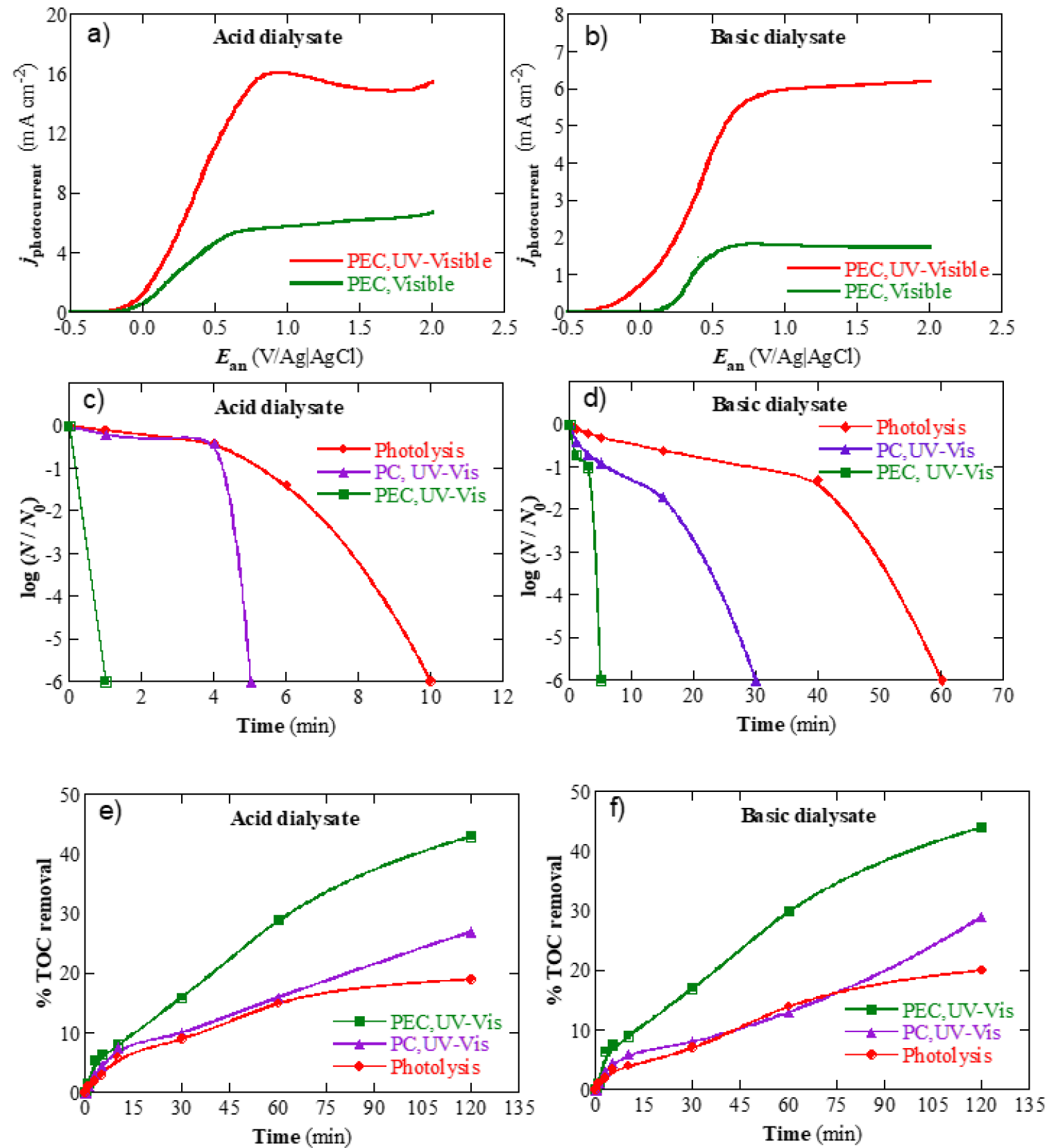

Figure 9. Photocurrent density vs. anodic potential determined for $250 \mathrm{~mL}$ of (a) acid dialysate (pH 2.8) and (b) basic dialysate $\left(\mathrm{pH}\right.$ 7.9) solutions using an air-stirred undivided three-electrode tank reactor with a nanoporous $\mathrm{W} / \mathrm{WO}_{3}$ photoanode, a Pt gauze cathode, and an $\mathrm{Ag} \mid \mathrm{AgCl}$ reference electrode, upon irradiation with a $125 \mathrm{~W} \mathrm{UV}-\mathrm{Vis}$ lamp. Inactivation of $10^{6} \mathrm{CFU} \mathrm{mL} \mathrm{m}^{-1}$ Candida parapsilosis spiked into the above (c) acid and (d) basic dialysates at $E_{\mathrm{an}}=+1.0$ $\mathrm{V} / \mathrm{Ag} \mid \mathrm{AgCl}$. (e,f) Percentage of TOC removal under the above conditions. Adapted from [39].

\subsection{Mycobacteria}

Mycobacteria are Gram-positive bacteria with over 100 species. The tuberculosis bacterium $M$. tuberculosis is a member of this genus. Other mycobacteria that do not cause tuberculosis are referred to as nontuberculous mycobacteria (NTM). Unfortunately, many of these NTMs are opportunistic human and animal pathogens that can cause a wide range of illnesses, such as pulmonary infections [81]. Mycobacteria are ubiquitous bacteria, since they have been detected in soil and in most types of water, such as surface waters (including marine waters), drinking water, and water plumbing systems [82]. In fact, a correlation between water age and the quantity of mycobacteria has been established [81]. Mycobacteria 
can thrive in conditions where other bacteria cannot survive and can thus remain in water as a pollutant for a long time. Some mycobacteria are persistent water pollutants in wastewater treatment plants and have been found in treated wastewater effluents, denoting their recalcitrant nature against conventional water treatment methods [83]. It is therefore necessary to apply powerful oxidative methods such as PEC for the complete elimination of these Mycobacteria from water.

The excellent inactivation ability of PEC for several species of mycobacteria has been confirmed by Zanoni's group in pure water. They disinfected aqueous solutions of $M$. kansasii and M. avium [22], M. smegmatis [58,84], M. fortuitum, M. chelonae, M. abscessus [85], and M. tuberculosis [86], using $\mathrm{Ti}_{\mathrm{I}} \mathrm{TiO}_{2}$ and $\mathrm{Ti} I \mathrm{TiO}_{2}-\mathrm{Ag}$ NTs photoanodes under UVA or visible illumination. For instance, $250 \mathrm{~mL}$ of $5 \times 10^{8} \mathrm{CFU} \mathrm{mL} \mathrm{m}^{-1} \mathrm{M}$. kansasii or $M$. avium [22] and $7 \times 10^{4} \mathrm{CFU} \mathrm{mL}{ }^{-1} \mathrm{M}$. smegmatis [58] in $0.05 \mathrm{M} \mathrm{Na}_{2} \mathrm{SO}_{4}$ were treated with an undivided three-electrode tank reactor submitted to external illumination with a 125 W UVA lamp. The reactor was equipped with a $\mathrm{Ti}_{\mathrm{I}} \mathrm{TiO}_{2}-\mathrm{Ag} \mathrm{NTs}$ photoanode and an $E_{\text {an }}$ $=+1.5 \mathrm{~V} / \mathrm{Ag} \mid \mathrm{AgCl}$ was provided for AO and PEC (see Table 1). Figure 10a,c depict that M. kansasii and M. avium were not abated by AO, poorly removed by photolysis and PC, and as expected, more effectively inactivated by PEC; although only 4.2 and 3.4 log units of them were reduced in 60-90 min. The evolution of polysaccharides and mycolic acids released during the treatments confirmed the cleavage of cell walls, being related to the TOC abatement of both solutions. The percent of TOC removal achieved by the different processes followed the same tendency as the inactivation, giving rise to a maximum reduction of $57 \%$ and $48 \%$ after 240 min of PEC for $M$. kansasii and M. avium, respectively, as can be seen in Figure 10b,d. In the case of M. smegmatis [58], a $150 \mathrm{~W}$ visible light was also used to illuminate a similar small reactor with $10 \mathrm{~mL}$ of solutions. Figure 10e clearly highlights the much better performance of UVA light compared to the visible light for cell inactivation, because the more energetic photons favored the production of $\mathrm{e}_{\mathrm{CB}}-\mathrm{h}_{\mathrm{VB}}{ }^{+}$ pairs from Reaction (1) and ROS to a much larger extent. This was reflected by the total mineralization achieved by the solution in $240 \mathrm{~min}$, with the UVA light better than the $37 \%$ TOC removal attained with visible light (see Figure 10f). These authors confirmed a negligible lixiviation of the surface $\mathrm{Ag}$ to $\mathrm{Ag}^{+}$that conferred a high stability to the $\mathrm{Ti} \mid \mathrm{TiO}_{2}-$ Ag NTs photoanode under the conditions tested. More research is needed to confirm the effectiveness of PEC for disinfecting real wastewaters contaminated with mycobacteria, including the study of energy costs for possible industrial applications. 

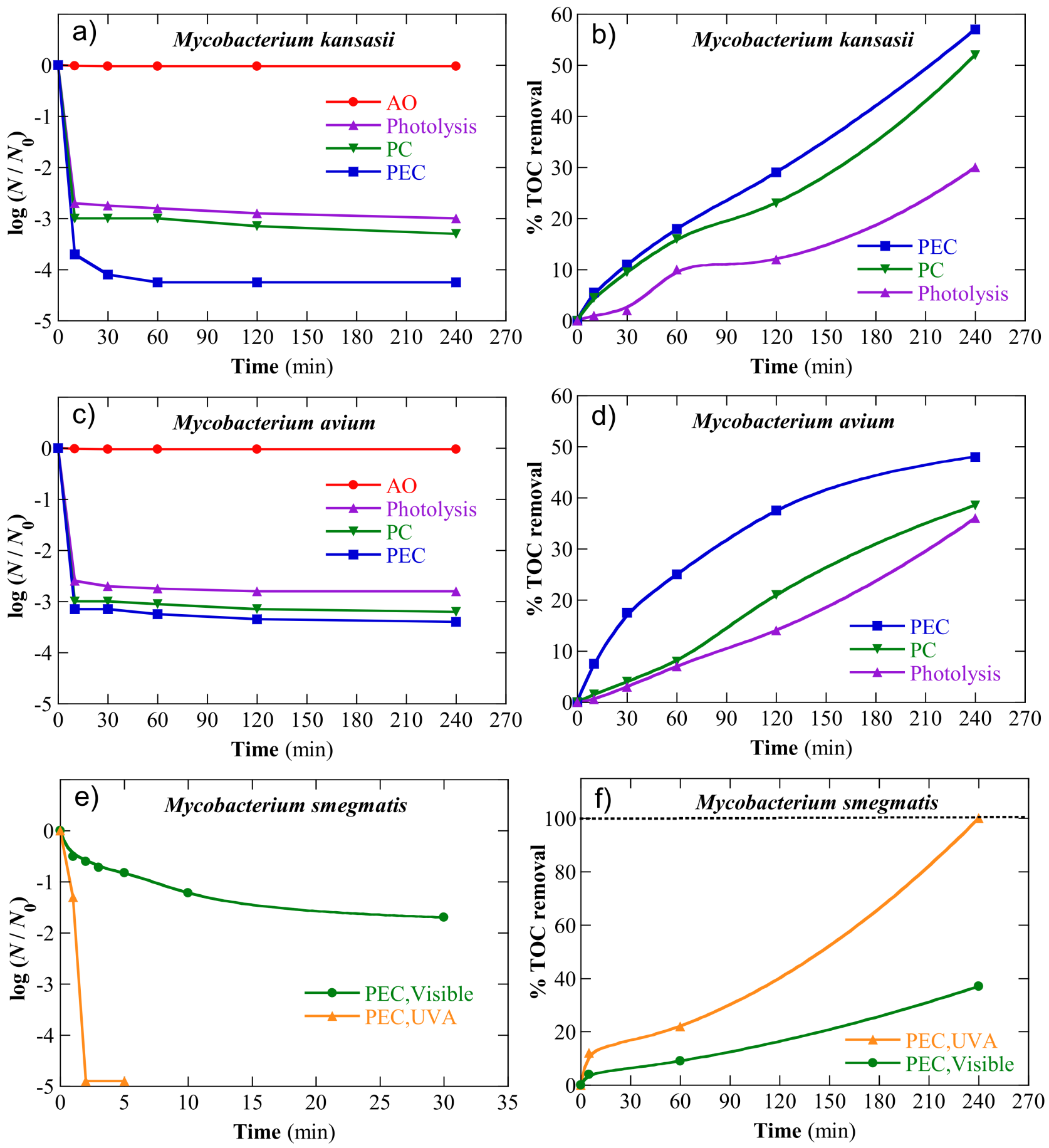

Figure 10. (a) Inactivation of $5 \times 10^{8} \mathrm{CFU} \mathrm{mL} \mathrm{m}^{-1}$ Mycobacterium kansasii and (b) percentage of TOC removal by $\mathrm{AO}$, photolysis, $\mathrm{PC}$, and PEC for $250 \mathrm{~mL}$ of bacteria suspension in pure water with $0.05 \mathrm{M} \mathrm{Na}_{2} \mathrm{SO}_{4}$ at $\mathrm{pH} 6.2$ using an undivided three-electrode tank reactor equipped with a $\mathrm{Ti}_{\mathrm{I}} \mathrm{TiO}_{2}-\mathrm{Ag} \mathrm{NPs}$ photoanode, a Pt gauze cathode, and an $\mathrm{Ag} \mid \mathrm{AgCl}$ reference electrode. In the photo-assisted processes the solution was illuminated with a $125 \mathrm{~W}$ UVA light. An $E_{\mathrm{an}}=+1.5 \mathrm{~V} / \mathrm{Ag} \mid \mathrm{AgCl}$ was applied in AO and PEC. (c) Inactivation of $5 \times 10^{8} \mathrm{CFU} \mathrm{mL} \mathrm{m}^{-1}$ Mycobacterium avium and (d) the corresponding percentage of TOC removal under the same conditions. Adapted from [22]. (e) Inactivation of $7 \times 10^{4} \mathrm{CFU} \mathrm{mL}^{-1} \mathrm{Mycobacterium}^{-}$ smegmatis and (f) the corresponding percent of TOC removal upon the above PEC conditions with UVA irradiation. For the PEC process with visible light, a photoreactor with $10 \mathrm{~mL}$ of solution submitted to a $150 \mathrm{~W}$ Xe lamp $(\lambda=420-630 \mathrm{~nm}) \mathrm{was}$ used. Adapted from [58]. 


\subsection{Other Microoganisms}

A few other microorganisms have been treated by $\mathrm{PEC}$ with $\mathrm{TiO}_{2}$ photoanodes, usually in pure water. The abatement of the cyanobacterium Microcystin aeruginosa [87]; the bacteria Staphylococcus aureus, Klebsiella pneumoniae, and Bacillus subtilis spores; the parasitic protozoan Cryptosporidium parvum [27]; and the bacteria Pseudonomas aeruginosa [59] and Legionella pneumophila [28] have been described, and, in many cases, compared with that of $E$. coli. Pseudonomas aeruginosa is a Gram-negative aerobic bacterium, ubiquitous in water and soils, that can cause infections such as otitis, keratitis, dermatitis, and pneumonia $[59,88]$. It is also a common bacteria that causes failure in water treatment systems such as filtration units [89]. Domínguez-Espíndola et al. [59] prepared $\mathrm{Ti} \mid \mathrm{TiO}_{2}-\mathrm{Ag}$ photoanodes with $1 \%$ and $4 \%$ surface Ag prepared to assess the effect of this metal on the PEC disinfection of this pathogen. Each photoanode was introduced into a stirred undivided three-electrode tank reactor and subjected to an $\mathrm{E}_{\mathrm{an}}$ value of +1.00 or $+1.70 \mathrm{~V} / \mathrm{Ag} \mathrm{I} \mathrm{AgCl}$ with an external $125 \mathrm{~W}$ UVC light. Under these conditions, $100 \mathrm{~mL}$ of $10^{6} \mathrm{CFU} \mathrm{mL}^{-1}$ cells suspended in 7-25 mM $\mathrm{Na}_{2} \mathrm{SO}_{4}$ at pH 5.9 and $25^{\circ} \mathrm{C}$ were treated for $40 \mathrm{~min}$. Figure 11a shows that at this time, total inactivation was achieved by $\mathrm{PC}$ in $25 \mathrm{mM} \mathrm{Na}_{2} \mathrm{SO}_{4}$; whereas, a much shorter time of 5 min was required by $\mathrm{PEC}$ at $\mathrm{E}_{\mathrm{an}}=+1.70 \mathrm{~V} / \mathrm{Ag} \mid \mathrm{AgCl}$. However, a longer time of $35 \mathrm{~min}$ was needed for overall inactivation when PEC was run with a smaller content of $7 \mathrm{mM}$ $\mathrm{Na}_{2} \mathrm{SO}_{4}$. The enhancement of the disinfection power with increasing $\mathrm{Na}_{2} \mathrm{SO}_{4}$ concentration can be ascribed to the formation of additional oxidizing species as disinfectants, such as sulfate anion radicals $\left(\mathrm{SO}_{4}{ }^{--}\right)$and peroxydisulfate $\left(\mathrm{S}_{2} \mathrm{O}_{8}{ }^{2-}\right)$ from the oxidation of $\mathrm{SO}_{4}{ }^{2-}$ at the anode [90]. The positive effect of the higher applied $\mathrm{E}_{\mathrm{an}}$ value and greater surface $\mathrm{Ag}$ in $25 \mathrm{mM} \mathrm{Na}_{2} \mathrm{SO}_{4}$, due to the larger production of $\mathrm{ROS}$ and other disinfectants and the disinfecting role of $\mathrm{Ag}$, respectively, on the cell inactivation by PEC can be inferred from Figure $11 b$ (see also Table 1).
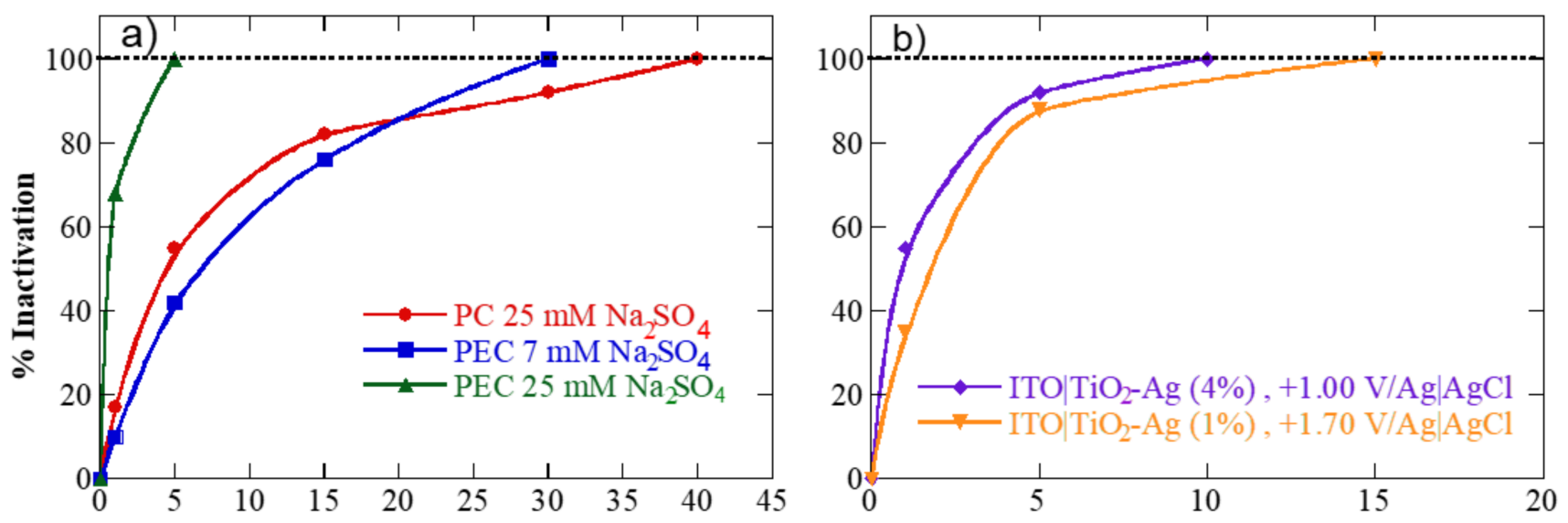

Time (min)

Figure 11. Percentage of inactivation with time for $10^{6} \mathrm{CFU} \mathrm{mL} \mathrm{m}^{-1}$ Pseudomonas aeruginosa in $100 \mathrm{~mL}$ of an aqueous suspension at $\mathrm{pH} 5.9$ and $25^{\circ} \mathrm{C}$ upon PEC treatment using a stirred undivided three-electrode tank reactor with an ITO I $\mathrm{TiO}_{2}$-Ag photoanode illuminated with a $125 \mathrm{~W}$ UVC light, a SS cathode, both of $3 \mathrm{~cm}^{2}$ area, and an $\mathrm{Ag} \mid \mathrm{AgCl}$ reference electrode. (a) Comparative PC treatment and effect of background electrolyte in PEC at $E_{\mathrm{an}}=+1.70 \mathrm{~V} / \mathrm{Ag} \mid \mathrm{AgCl}$. (b) Effect of the $\mathrm{Ag}$ load on $\mathrm{TiO}_{2}$ and $E_{\mathrm{an}}$ for $25 \mathrm{mM} \mathrm{Na}_{2} \mathrm{SO}_{4}$. Adapted from [59].

The Gram-negative Legionella pneumophila is normally present in both natural and artificial water systems and can cause respiratory diseases. For the disinfection of L. pneumophila, Montenegro-Ayo et al. [28] designed an autonomous photoelectrocatalytic reactor (Figure 3e) that contained $350 \mathrm{~mL}$ of solution in contact with a $\mathrm{Ti}_{\text {I }} \mathrm{TiO}_{2} \mathrm{NTs}_{\text {photonode }}$ with an inner UV-LED illumination. The electrical energy required by the lamp and the reactor were provided by a battery. In $0.50 \mathrm{M} \mathrm{Na}_{2} \mathrm{SO}_{4}$ and by applying a very low current of $5 \mathrm{~mA}$, a $2.6 \log$ units reduction was determined after 60 min of PEC treatment of $3.3 \times$ $10^{5} \mathrm{CFU} \mathrm{mL}{ }^{-1}$ L. pneumophila. This pathogen was more resistant to the attack of generated 
disinfectants than E. coli, which was reduced by 5 log units from a content of $10^{5} \mathrm{CFU}$ $\mathrm{mL}^{-1}$ after $10 \mathrm{~s}$ under the same operating conditions.

\section{Mechanisms of Bacteria Inactivation}

The large variety of existing pathogens and their cell complexity make it difficult to establish general mechanisms for bacteria inactivation. As a general rule, photoelectrocatalytic disinfection involves drastic morphological changes to the cell, provoking in most cases membrane cleavage or lysis due to the attack of the oxidizing agents, pre-eminently ROS, originated from the photogenerated charge carriers $\left(\mathrm{e}_{\mathrm{CB}}{ }^{-}\right.$and $\left.\mathrm{h}_{\mathrm{VB}}{ }^{+}\right)$. Some examples are collected in Figure 12 to show this behavior in scanning electron microscopy (SEM) images obtained for several untreated and treated cells. Figure 12a shows the change in morphology of E. coli when $50 \mathrm{~mL}$ of $1.2 \times 10^{6} \mathrm{CFU} \mathrm{mL} \mathrm{mL}^{-1}$ bacteria in urban wastewater was submitted to PEC using a system similar to that of Figure $3 \mathrm{~d}$ with an $\mathrm{Al} / \mathrm{TiO}_{2}-\mathrm{Ag}$ photoanode at a cell voltage of $1.5 \mathrm{~V}$ for $30 \mathrm{~min}$ with an external $4 \mathrm{~W}$ UVA irradiation [23]. While the healthy, viable untreated pathogens presented a well-defined morphology with smooth surface, the treated cells became rough with a crumbled form, as result of the oxidative action of ROS on the membrane, cytoplasm, and nucleus of the cell. Figure $12 \mathrm{~b}$ depicts the inactivation of $E$. coli by PC and PEC for samples of $9.0 \times 10^{6} \mathrm{CFU} \mathrm{mL}^{-1}$ in $0.1 \mathrm{M} \mathrm{NaNO}_{3}$ without and with $1.0 \mathrm{mM} \mathrm{Br}^{-}$, using a flow cell equipped with a $\mathrm{Ti}^{-1} \mathrm{TiO}_{2}$ photoanode exposed to an UV-LED lamp [64]. Severe damage to the cell membrane can be observed for long treatment times by PC and PEC (at $E_{\mathrm{an}}=+0.30 \mathrm{~V} / \mathrm{Ag} \mid \mathrm{AgCl}$ ) without $\mathrm{Br}^{-}$, which mainly occurred on the cell body parts in contact with the $\mathrm{TiO}_{2}$ surface, where the generated ROS accumulated. In contrast, the presence of $1.0 \mathrm{mM} \mathrm{Br}^{-}$yielded a much faster and severe cell damage in a short PEC time, taking place in all of the solution due to the oxidative participation of additionally generated reactive bromine species $\left(\mathrm{Br}^{\bullet}\right.$ and $\mathrm{Br}_{2}{ }^{-}{ }^{-}$). For the inactivation of P. aeruginosa, Figure 12c highlights the morphological changes observed for $100 \mathrm{~mL}$ of $10^{6} \mathrm{CFU} \mathrm{mL} \mathrm{mL}^{-1}$ cells in a sulfate medium at $\mathrm{pH} 5.9$ upon PEC treatment using a stirred undivided three-electrode tank reactor with an $\mathrm{Ti}^{\prime} \mathrm{TiO}_{2}-\mathrm{Ag}$ photoanode and illuminated with a $125 \mathrm{~W}$ UVC light at $E_{\mathrm{an}}=+1.70 \mathrm{~V} / \mathrm{Ag} \mid \mathrm{AgCl}$ for 5 min [59]. The surface of the treated cells became much rougher than those untreated, and some of them were lysed and collapsed, releasing cellular debris. This indicates the importance of the oxidation of the wall architecture by the generated ROS, which causes the loss of cytoplasmic material, leading to the death of the cells. 
a)

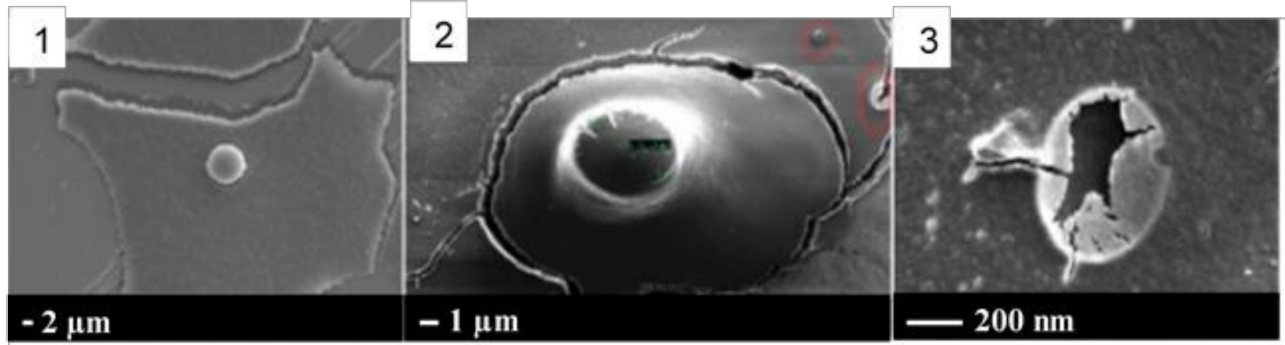

b)

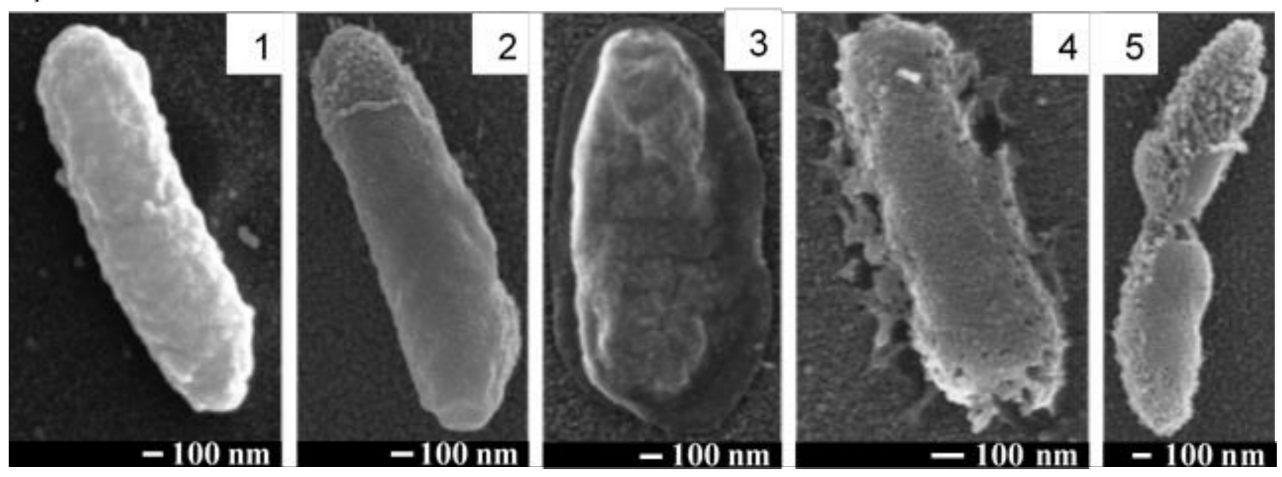

C)
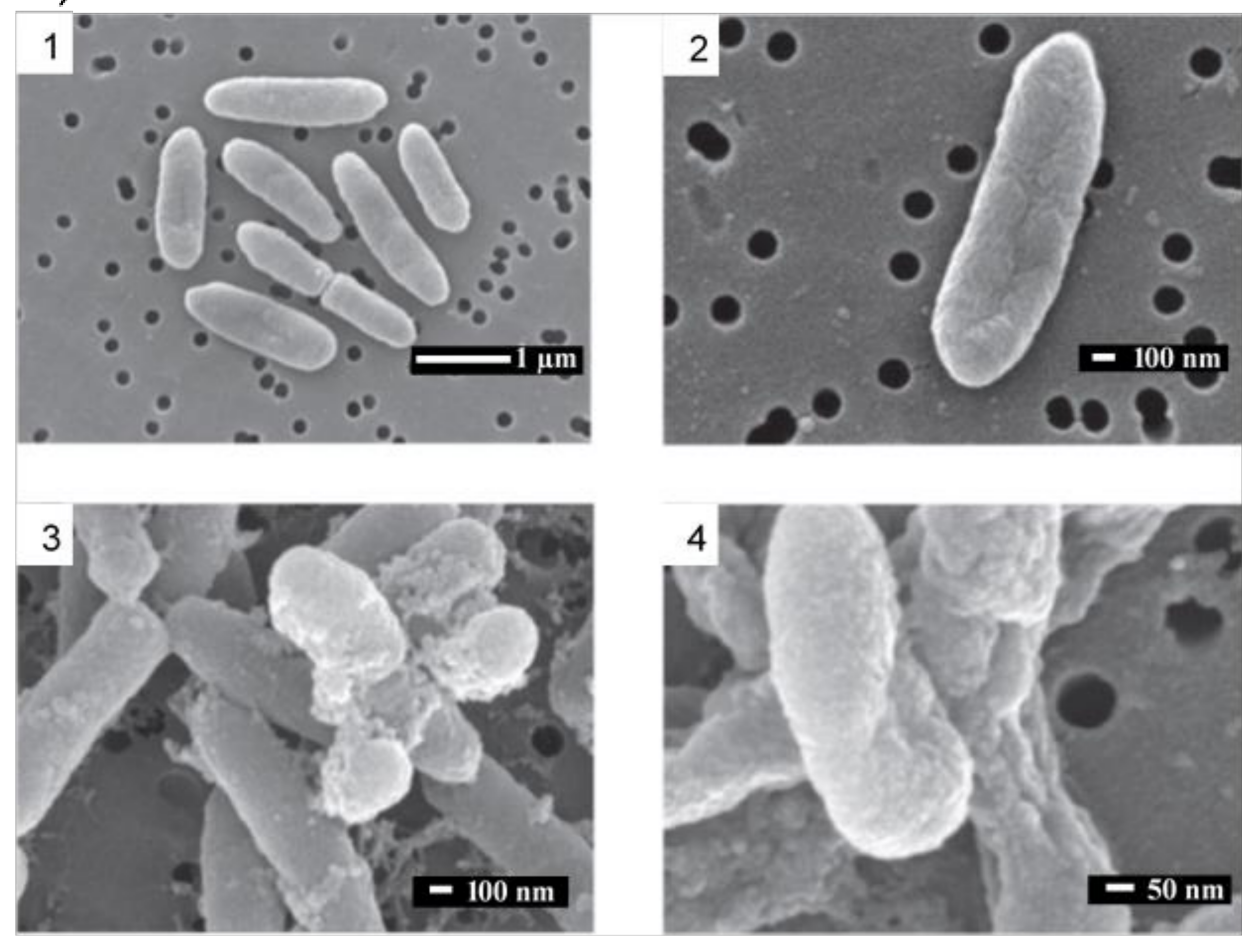

Figure 12. SEM images of: (a) (1) untreated and (2,3) inactivated E. coli by PEC with an Ag-decorated $\mathrm{TiO}_{2}$ I Ti photoanode and a $4 \mathrm{~W}$ UVA light (reproduced from [23]), (b) (1) untreated Escherichia coli, and after (2) $900 \mathrm{~s}$ of PC, (3) $60 \mathrm{~s}$ of PEC, (4) $300 \mathrm{~s}$ of PEC, and (5) $60 \mathrm{~s}$ of PEC in the presence of $\mathrm{Br}^{-}$, always using a $\mathrm{Ti} \mid \mathrm{TiO}_{2}$ photoanode with an UV-LED light $\left(\lambda_{\max }=365 \mathrm{~nm}\right.$ ) (reproduced from [64]), and (c) $(1,2)$ initial and $(3,4)$ inactivated $P$. aeruginosa by PEC with an Ag-decorated $\mathrm{TiO}_{2} \mid \mathrm{Ti}$ photoanode irradiated with a 125 W UVC light (reproduced from [59]). 
It has been found that about $96 \%(w / w)$ of the dry weight of a bacterium is composed of organic macromolecules, including lipids, lipopolysaccharides, polysaccharides, and nucleic acids (RNA and DNA) [57]. These organics can be either partially or completely destroyed during PEC treatment. Several parameters can be measured to corroborate the damage of the cell by the generated disinfectants, such as the permeability and total protein content, lipids, cellular ATP level, intracellular enzyme, membrane potential, and $\mathrm{K}^{+}$leakage, among others [91]. In this context, TOC decay has been proposed to give indirect information about the oxidation of organic macromolecules caused by cell lysis [39,86]. The killing of cells from wall oxidation, followed by lysing and oxidation of internal cellular components is due to the loss of essential functions. For example, the presence of $\mathrm{K}^{+}$in a bacterial cell facilitates the activation of intracellular enzymes, osmosis, and $\mathrm{pH}$ regulation [74], and its output decreases the cell viability and favors the oxidation of polyunsaturated phospholipids present in the cell membrane, losing respiration ability $[23,84]$. It has also been documented that DNA and proteins can bind to oxidized lipids, hindering their regeneration and causing cell death [84]. However, several studies have described other types of DNA damage, such as photo-modification of nitrogenous bases and double-strand rupture, which can be repaired by the cell allowing its survival and reproduction over a long-time frame. This occurs when microorganisms are submitted to UVC photolysis, since part of the backbone structure of ADN is maintained and can be repaired by the cell $[39,57]$. In contrast, the strong disinfection oxidants produced in PEC yield irreversible DNA damage, with the consequent death of the bacteria. Several authors have confirmed the destruction of specific molecules by PEC, such as the antibiotic-resistance genes blaTEM-1 and aac(3)-II of E. coli [69] and the polysaccharides and mycolic acids of M. kansasii and M. avium [22].

Attention has been paid to the generation and action of disinfecting agents in PEC aiming to elucidate a reaction mechanism for bacteria disinfection. As stated above, in a free-chloride medium, the photogenerated $\mathrm{h}_{\mathrm{VB}}{ }^{+}$and $\mathrm{e}_{\mathrm{CB}}{ }^{-}$via Reaction (1) produce the oxidants ${ }^{\bullet} \mathrm{OH}$ and $\mathrm{O}_{2}{ }^{\bullet-}$ from Reactions (2) and (3), respectively. Moreover, $\mathrm{h}_{\mathrm{VB}}{ }^{+}$can also act as an oxidant center of organics, whereas $\mathrm{O}_{2}{ }^{-}$can evolve to other weaker oxidants, such as $\mathrm{HO}_{2}{ }^{\bullet}$ and $\mathrm{H}_{2} \mathrm{O}_{2}$ [30]. All these species can kill the bacteria in $\mathrm{PC}$, albeit slowly because they are produced in low concentrations due to the fast disappearance of the charge carriers by the recombination Reaction (4) [64]. In contrast, the extraction of $\mathrm{e}_{\mathrm{CB}}{ }^{-}$ from the photoanode towards the cathode in PEC drastically prolongs the lifetime of $\mathrm{h}_{\mathrm{VB}}{ }^{+}$, and this species, and particularly ${ }^{\bullet} \mathrm{OH}$, become the main disinfectant agents $[23,64]$. This point has been confirmed from the inactivation of $10^{3} \mathrm{CFU} \mathrm{mL}{ }^{-1}$ E. coli in synthetic fish farm wastewater at $\mathrm{pH} 6.2$ using $\mathrm{Ti}^{\mathrm{I}} \mathrm{TiO}_{2}$ supported by GAC for PEC under a 6 W UVA light [71]. Figure $5 \mathrm{c}$ discloses the close relationship between the rate of ${ }^{\bullet} \mathrm{OH}$ generation and the log cell unit decay, demonstrating the good disinfection power of this radical. The situation is more complicated when the aqueous matrix contains $\mathrm{Cl}^{-}$ ion, as in the case of real wastewaters. Active chlorine is then largely formed from $\mathrm{Cl}^{-}$ oxidation at the anode, as a strong disinfectant, and competes with ${ }^{\circ} \mathrm{OH}$ to inactivate the cells. However, radical active chlorine $\left(\mathrm{Cl}^{\bullet}\right.$ and $\left.\mathrm{Cl}_{2}{ }^{\bullet-}\right)$ and bromine $\left(\mathrm{Br}^{\bullet}\right.$ and $\left.\mathrm{Br}_{2}{ }^{\bullet-}\right)$ species can also be generated, and depending on the nature of the aqueous matrix, they create other disinfectant and toxic byproducts like dichloroacetic acid, bromochloroacetic acid, and bromodichloromethane $[68,92]$. The joint and parallel attack of all these disinfectants accelerates the death of bacteria in real wastewaters, but their partial consumption by organic pollutants and/or NOM inhibits their inactivation power.

Deeper research efforts are required to better understand the inactivation mechanisms of the generated disinfecting agents in different aqueous solutions by PEC. In light of this, the extensive work of Long et al. [91] on the removal of E. coli in sulfate, phosphate, and chloride media by AO with a boron-doped diamond/SS cell, where the main oxidant was the heterogeneous ${ }^{\bullet} \mathrm{OH}$ formed at the anode surface from water oxidation, is remarkable. Oxidants such as $\mathrm{S}_{2} \mathrm{O}_{8}{ }^{2-}$ and peroxydiphosphate $\left(\mathrm{P}_{2} \mathrm{O}_{8}{ }^{4-}\right)$ are also generated in sulfate and phosphate media, respectively. From the analysis of different parameters related to the subcellular mechanisms of bacterial damage, these authors concluded the following: 
(i) In sulfate medium, inactivation is mainly induced by the oxidation of proteins related to the $\mathrm{K}^{+}$transport, thus hindering the ATP synthesis and the subcellular localization of cell division protein,

(ii) In phosphate medium, total destruction is achieved due to the overall mineralization of intracellular enzymes, alongside total and membrane proteins, and

(iii) In chloride medium, the attack of ${ }^{\bullet} \mathrm{OH}$ heterogeneous and active chlorine caused the degradation of intracellular enzymatic systems and the death of the cells.

The subcellular processes taking place in PEC should then be closely analyzed to identify the oxidized macromolecules that inactivated the cell. This could help in the establishment of cost-effective optimum conditions for the treatment of real wastewater using this technique.

\section{Conclusions and Prospects}

Photoelectrocatalysis is a versatile technology that can provide unique opportunities for decentralized and autonomous water disinfection. Enabling access to clean water would have a drastic impact in the quality of life globally. In situ disinfection can minimize the reliance on chlorine-based disinfectants and decrease the health impact of carcinogenic disinfectant by-products. Experimental results demonstrate excellent prospects for the advancement of PEC to a higher technological readiness level, but several aspects should be further investigated.

Material selection is a key element that may affect the overall cost of a treatment unit, especially if these costs are assumed by the final user. Thus, the photoanode material and selection of photoelectrode substrate become key aspects that have not been devoted the required attention. Other photoelectrocatalytic materials beyond $\mathrm{TiO}_{2}$ have been barely studied, which provides many opportunities for further exploration with more cost-effective systems, illuminated/powered with free natural sunlight. The evaluation of new materials has to be supported with mechanistic studies of inactivation, since a few studies hint that different types of semiconductors (i.e., $n$-type and $p$-type) may enable different inactivation mechanisms for bacteria and fungi.

As commonly seen in other light-driven catalytic technologies, PEC disinfection has a major barrier to its commercialization: the few and infrequent advances in engineering reactor design. There are still open questions regarding the best approach to deploying PEC technologies, as discussed herein. The marriage between light-delivery and electrochemical needs in this intensified hybrid process is indeed challenging, and not trivial. Future research should explore the competitiveness of PEC as a batch treatment system (e.g., the portable autonomous photoelectrocatalytic disinfection device of Figure 3f) or as continuous flow reactor devices capable of treating larger volumes of water. Researchers and engineers should decide if the delivery of treated water will come directly from the reactor device or should be stored for consumption. Furthermore, in the latter case, long-standing inactivation should be evaluated to discount bacteria/fungi regrowth after treatment.

Effective and fast inactivation of bacteria and fungi has been reported, but the mechanisms of bacteria inactivation/disruption are not fully-understood. Several water matrix effects may play a significant role, while involving the generation of different oxidants with different half-lives (i.e., hydroxyl radical vs. chlorine). Systematic studies that complete the missing pieces of PEC bacterial inactivation will contribute to enlightening the pathway for technological translation. This understanding will be essential to warrant the approval of the entities responsible for the safety of drinking water (e.g., the Food and Drug Administration (FDA) and the Environmental Protection Agency (EPA) in the US).

Author Contributions: Conceptualization, S.G.-S., O.A.A., E.B., validation, S.G.-S., O.A.A., E.B.; formal analysis, S.G.-S., O.A.A., E.B.; resources, S.G.-S., O.A.A., E.B., data curation, S.G.-S., O.A.A., E.B., writing-original draft preparation, S.G.-S., O.A.A., E.B.; writing—review and editing, S.G.S., O.A.A., E.B.; visualization, E.B. All authors have read and agreed to the published version of the manuscript. 
Funding: This work was funded by the National Science Foundation (EEC-1449500) Nanosystems Engineering Research Center on Nanotechnology-Enabled Water Treatment, and The National Research Foundation of South Africa (CPRR 118546).

Data Availability Statement: Data is contained within the article.

Conflicts of Interest: The authors declare no conflict of interest. The funders had no role in the design of the study; in the collection, analyses, or interpretation of data; in the writing of the manuscript; or in the decision to publish the results.

\section{References}

1. United Nations Resolution 64/292. The Human Right to Water and Sanitation. 2010. Available online: https:/ /www.un.org/ waterforlifedecade/pdf/human_right_to_water_and_sanitation_media_brief.pdf (accessed on 28 June 2021).

2. United Nations Sustainable Developement Goals. Available online: https://sustainabledevelopment.un.org/sdg6 (accessed on 28 June 2021).

3. Donde, O.O.; Atoni, E.; Muia, A.W.; Yillia, P.T. COVID-19 pandemic: Water, sanitation and hygiene (WASH) as a critical control measure remains a major challenge in low-income countries. Water Res. 2021, 191, 2016-2021. [CrossRef]

4. Marcos-Garcia, P.; Carmona-Moreno, C.; López-Puga, J.; Ruiz-Ruano García, A.M. COVID-19 pandemic in Africa: Is it time for water, sanitation and hygiene to climb up the ladder of global priorities? Sci. Total Environ. 2021, 791, 148252. [CrossRef]

5. Poliakoff, M.; Licence, P.; George, M.W. UN sustainable development goals: How can sustainable/green chemistry contribute? By doing things differently. Curr. Opin. Green Sustain. Chem. 2018, 13, 146-149. [CrossRef]

6. Mondejar, M.E.; Avtar, R.; Diaz, H.L.B.; Dubey, R.K.; Esteban, J.; Gomez-Morales, A.; Hallam, B.; Mbungi, N.T.; Okolo, C.C.; Prasad, K.A.; et al. Digitalization to achieve sustainable development goals: Steps towards a smart green plane. Sci. Total Environ. 2021, 794, 148539. [CrossRef]

7. Cutler, D.; Miller, G. The role of public health improvements in health advances: The twentieth-century United States. Demography 2005, 42, 1-22. [CrossRef]

8. Pichel, N.; Vivar, M.; Fuentes, M. The problem of drinking water access: A review of disinfection technologies with an emphasis on solar treatment methods. Chemosphere 2019, 218, 1014-1030. [CrossRef]

9. Blue, G.; Bronson, K.; Lajoie-O'Malley, A. Beyond distribution and participation: A scoping review to advance a comprehensive environmental justice framework for impact assessment. Environ. Impact Assess. Rev. 2021, 90, 106607. [CrossRef]

10. Jung, Y.T.; Narayanan, N.C.; Cheng, Y.L. Cost comparison of centralized and decentralized wastewater management systems using optimization model. J. Environ. Manag. 2018, 213, 90-97. [CrossRef] [PubMed]

11. Fiebelkorn, A.P.; Person, B.; Quick, R.E.; Vindigni, S.M.; Jhung, M.; Bowen, A.; Riley, P.L. Systematic review of behavior change research on point-of-use water treatment interventions in countries categorized as low- to medium-development on the human development index. Soc. Sci. Med. 2012, 75, 622-633. [CrossRef] [PubMed]

12. Bessegato, G.G.; Guaraldo, T.T.; de Brito, J.F.; Brugnera, M.F.; Zanoni, M.V.B. Achievements and trends in photoelectrocatalysis: From environmental to energy applications. Electrocatalysis 2015, 6, 415-441. [CrossRef]

13. Collivignarelli, M.C.; Abbà, A.; Miino, M.C.; Caccamo, F.M.; Torretta, V.; Rada, E.C.; Sorlini, S. Disinfection of wastewater by uv-based treatment for reuse in a circular economy perspective. Where are we at? Int. J. Environ. Res. Public Health 2021, 18, 77. [CrossRef] [PubMed]

14. Fujishima, A.; Honda, K. Electrochemical photolysis of water at a semiconductor electrode. Nature 1972, 238, 37-38. [CrossRef] [PubMed]

15. Garcia-Segura, S.; Brillas, E. Applied photoelectrocatalysis on the degradation of organic pollutants in wastewaters. J. Photochem. Photobiol. C Photochem. Rev. 2017, 31, 1-35. [CrossRef]

16. McMichael, S.; Fernández-Ibáñez, P.; Byrne, J.A. A review of photoelectrocatalytic reactors for water and wastewater treatment. Water 2021, 13, 1198. [CrossRef]

17. Tugaoen, H.O.N.; Garcia-Segura, S.; Hristovski, K.; Westerhoff, P. Compact light-emitting diode optical fiber immobilized TiO 2 reactor for photocatalytic water treatment. Sci. Total Environ. 2018, 613-614, 1331-1338. [CrossRef]

18. Fagan, R.; McCormack, D.E.; Dionysiou, D.D.; Pillai, S.C. A review of solar and visible light active $\mathrm{TiO}_{2}$ photocatalysis for treating bacteria, cyanotoxins and contaminants of emerging concern. Mater. Sci. Semicond. Process. 2016, 42, 2-14. [CrossRef]

19. Dosta, S.; Robotti, M.; Garcia-Segura, S.; Brillas, E.; Cano, I.G.; Guilemany, J.M. Influence of atmospheric plasma spraying on the solar photoelectro-catalytic properties of $\mathrm{TiO}_{2}$ coatings. Appl. Catal. B Environ. 2016, 189, 151-159. [CrossRef]

20. Marcelino, R.B.P.; Amorim, C.C. Towards visible-light photocatalysis for environmental applications: Band-gap engineering versus photons absorption-A review. Environ. Sci. Pollut. Res. 2019, 26, 4155-4170. [CrossRef]

21. Villaluz, F.J.A.; de Luna, M.D.G.; Colades, J.I.; Garcia-Segura, S.; Lu, M.-C. Removal of 4-chlorophenol by visible-light photocatalysis using ammonium iron (II) sulfate-doped nano-titania. Process Saf. Environ. Prot. 2019, 125, 121-128. [CrossRef]

22. Brugnera, M.F.; Miyata, M.; Zocolo, G.J.; Fujimura Leite, C.Q.; Boldrin Zanoni, M.V. A photoelectrocatalytic process that disinfects water contaminated with Mycobacterium kansasii and Mycobacterium avium. Water Res. 2013, 47, 6596-6605. [CrossRef] [PubMed] 
23. Domínguez-Espíndola, R.B.; Varia, J.C.; Álvarez-Gallegos, A.; Ortiz-Hernández, M.L.; Peña-Camacho, J.L.; Silva-Martínez, S. Photoelectrocatalytic inactivation of fecal coliform bacteria in urban wastewater using nanoparticulated films of $\mathrm{TiO}_{2}$ and $\mathrm{TiO}_{2} /$ Ag. Environ. Technol. 2017, 38, 606-614. [CrossRef] [PubMed]

24. Patnaik, S.; Martha, S.; Madras, G.; Parida, K. The effect of sulfate pre-treatment to improve the deposition of Au-nanoparticles in a gold-modified sulfated $\mathrm{g}-\mathrm{C}_{3} \mathrm{~N}_{4}$ plasmonic photocatalyst towards visible light induced water reduction reaction. Phys. Chem. Chem. Phys. 2016, 18, 28502-28514. [CrossRef] [PubMed]

25. Garcia-Segura, S.; Tugaoen, H.O.N.; Hristovski, K.; Westerhoff, P. Photon flux influence on photoelectrochemical water treatment. Electrochem. Commun. 2018, 87, 63-65. [CrossRef]

26. Mais, L.; Mascia, M.; Palmas, S.; Vacca, A. Photoelectrochemical oxidation of phenol with nanostructured $\mathrm{TiO}_{2}-\mathrm{PANI}$ electrodes under solar light irradiation. Sep. Purif. Technol. 2019, 208, 153-159. [CrossRef]

27. Cho, M.; Cates, E.L.; Kim, J.H. Inactivation and surface interactions of MS-2 bacteriophage in a $\mathrm{TiO}_{2}$ photoelectrocatalytic reactor. Water Res. 2011, 45, 2104-2110. [CrossRef]

28. Montenegro-Ayo, R.; Barrios, A.C.; Mondal, I.; Bhagat, K.; Morales-Gomero, J.C.; Abbaszadegan, M.; Westerhoff, P.; Perreault, F.; Garcia-Segura, S. Portable point-of-use photoelectrocatalytic device provides rapid water disinfection. Sci. Total Environ. 2020, 737, 140044. [CrossRef]

29. Montenegro-Ayo, R.; Morales-Gomero, J.C.; Alarcon, H.; Cotillas, S.; Westerho, P.; Garcia-Segura, S. Scaling up photoelectrocatalytic reactors: $\mathrm{A} \mathrm{TiO}_{2}$ nanotube-coated disc compound reactor effectively degrades acetaminophen. Water 2019, 11, 2522. [CrossRef]

30. Salmerón, I.; Sharma, P.K.; Polo-López, M.I.; Tolosana, A.; McMichael, S.; Oller, I.; Byrne, J.A.; Fernández-Ibáñez, P. Electrochemically assisted photocatalysis for the simultaneous degradation of organic micro-contaminants and inactivation of microorganisms in water. Process Saf. Environ. Prot. 2021, 147, 488-496. [CrossRef]

31. Chang, H.C.; Huang, H.H.; Wu, C.Y.; Hsu, R.Q.; Hsu, C.Y. The photocatalytic activity and compact layer characteristics of TiO 2 films prepared using radio frequency magnetron sputtering. Int. J. Photoenergy 2014, 2014, 786165. [CrossRef]

32. Serrà, A.; Philippe, L.; Perreault, F.; Garcia-Segura, S. Photocatalytic treatment of natural waters. Reality or hype? The case of cyanotoxins remediation. Water Res. 2021, 188, 116543. [CrossRef]

33. Dimapilis, E.A.S.; Hsu, C.; Mendoza, R.M.O.; Lu, M. Zinc oxide nanoparticles for water disinfection. Sustain. Environ. Res. 2018, 28, 47-56. [CrossRef]

34. Serrà, A.; Zhang, Y.; Sepúlveda, B.; Gómez, E.; Nogués, J.; Michler, J.; Philippe, L. Highly active ZnO-based biomimetic fern-like microleaves for photocatalytic water decontamination using sunlight. Appl. Catal. B Environ. 2019, 248, 129-146. [CrossRef]

35. Cerrón-Calle, G.A.; Aguirre, A.A.; Luyo, C.; Garcia-Segura, S.; Alarcón, H. Photoelectrocatalytic decolorization of azo dyes with nano-composite oxide layers of ZnO nanorods decorated with Ag nanoparticles. Chemosphere 2019, 219, 296-304. [CrossRef]

36. Serrà, A.; Artal, R.; García-Amorós, J.; Sepúlveda, B.; Gómez, E.; Nogués, J.; Philippe, L. Hybrid Ni@ZnO@ZnS-microalgae for circular economy: A smart route to the efficient integration of solar photocatalytic water decontamination and bioethanol production. Adv. Sci. 2020, 7, 1-9. [CrossRef]

37. Brillas, E.; Serrà, A.; Garcia-Segura, S. Biomimicry designs for photoelectrochemical systems: Strategies to improve light delivery efficiency. Curr. Opin. Electrochem. 2021, 26, 100660. [CrossRef]

38. Eswar, N.K.R.; Singh, S.A.; Madras, G. Photoconductive network structured copper oxide for simultaneous photoelectrocatalytic degradation of antibiotic (tetracycline) and bacteria (E. coli). Chem. Eng. J. 2018, 332, 757-774. [CrossRef]

39. Souza, B.A.; Perini, J.A.; Giannini, M.J.S.M.; Zanoni, M.V.B. Fast removal of Candida parapsilosis from hemodialysis dialysate using ultraviolet or visible light at nanoporous $\mathrm{W} / \mathrm{WO}_{3}$ electrodes. J. Environ. Chem. Eng. 2019, 7, 103104. [CrossRef]

40. Byrne, C.; Subramanian, G.; Pillai, S.C. Recent advances in photocatalysis for environmental applications. J. Environ. Chem. Eng. 2018, 6, 3531-3555. [CrossRef]

41. Garcia-Segura, S.; Qu, X.; Alvarez, P.J.J.; Chaplin, B.P.; Chen, W.; Crittenden, J.C.; Feng, Y.; Gao, G.; He, Z.; Hou, C.H.; et al. Opportunities for nanotechnology to enhance electrochemical treatment of pollutants in potable water and industrial wastewater-A perspective. Environ. Sci. Nano 2020, 7, 2178-2194. [CrossRef]

42. Putta, T.; Lu, M.C.; Anotai, J. Photocatalytic activity of tungsten-doped $\mathrm{TiO}_{2}$ with hydrothermal treatment under blue light irradiation. J. Environ. Manag. 2011, 92, 2272-2276. [CrossRef]

43. Al-Mamun, M.R.; Kader, S.; Islam, M.S.; Khan, M.Z.H. Photocatalytic activity improvement and application of UV-TiO 2 photocatalysis in textile wastewater treatment: A review. J. Environ. Chem. Eng. 2019, 7, 103248. [CrossRef]

44. Jayaraman, T.; Raja, S.A.; Priya, A.; Jagannathan, M.; Ashokkumar, M. Synthesis of visible-light active $\mathrm{V}_{2} \mathrm{O}_{5} / g-\mathrm{C}_{3} \mathrm{~N}_{4}$ heterojunction as an efficient photocatalytic and photoelectrochemical performance. New J. Chem. 2015, 39, 1367-1374. [CrossRef]

45. Oliveros, A.N.; Pimentel, J.A.I.; de Luna, M.D.G.; Garcia-Segura, S.; Abarca, R.R.M.; Doong, R.A. Visible-light photocatalytic diclofenac removal by tunable vanadium pentoxide/boron-doped graphitic carbon nitride composite. Chem. Eng. J. 2021, 403, 126213. [CrossRef]

46. Chen, J.; Loeb, S.; Kim, J. LED revolution: Fundamentals and prospects for UV disinfection applications. Environ. Sci. Water Res. Technol. 2017, 3, 188-202. [CrossRef]

47. Pirsaheb, M.; Hoseini, H.; Abtin, V. Photoelectrocatalytic degradation of humic acid and disinfection over $\mathrm{Ni}_{\mathrm{TiO}}-\mathrm{Ni} / \mathrm{AC}-\mathrm{PTFE}$ electrode under natural sunlight irradiation: Modeling, optimization and reaction pathway. J. Taiwan Inst. Chem. Eng. 2021, 118, 204-214. [CrossRef] 
48. Montenegro-Ayo, R.; Morales-Gomero, J.C.; Alarcon, H.; Corzo, A.; Westerhoff, P.; Garcia-Segura, S. Photoelectrocatalytic degradation of 2,4-dichlorophenol in a $\mathrm{TiO}_{2}$ nanotube-coated disc flow reactor. Chemosphere 2021, 268, 129320. [CrossRef] [PubMed]

49. Rahmawati, F.; Kusumaningsih, T.; Hastuti, A. Photo- and electro-catalysis for solar disinfection of Escherichia coli-contaminated water using $\mathrm{Ag}-\mathrm{TiO}_{2}$ /graphite. Toxicol. Environ. Chem. 2011, 93, 1602-1612. [CrossRef]

50. Philippidis, N.; Nikolakaki, E.; Sotiropoulos, S.; Poulios, I. Photoelectrocatalytic inactivation of E. coli XL-1 blue colonies in water. J. Chem. Technol. Biotechnol. 2010, 85, 1054-1060. [CrossRef]

51. Li, G.; Liu, X.; Zhang, H.; Wong, P.K.; An, T.; Zhao, H. Comparative studies of photocatalytic and photoelectrocatalytic inactivation of E. coli in presence of halides. Appl. Catal. B Environ. 2013, 140-141, 225-232. [CrossRef]

52. Liu, X.; Zhang, H.; Liu, C.; Chen, J.; Li, G.; An, T.; Wong, P.K.; Zhao, H. UV and visible light photoelectrocatalytic bactericidal performance of $100 \%$ \{ $\left.\begin{array}{lll}1 & 1 & 1\end{array}\right\}$ faceted rutile $\mathrm{TiO}_{2}$ photoanode. Catal. Today 2014, 224, 77-82. [CrossRef]

53. Baram, N.; Starosvetsky, D.; Starosvetsky, J.; Epshtein, M.; Armon, R.; Ein-Eli, Y. Enhanced inactivation of E. coli bacteria using immobilized porous $\mathrm{TiO}_{2}$ photoelectrocatalysis. Electrochim. Acta 2009, 54, 3381-3386. [CrossRef]

54. Pablos, C.; Marugán, J.; Van Grieken, R.; Dunlop, P.S.M.; Hamilton, J.W.J.; Dionysiou, D.D.; Byrne, J.A. Electrochemical enhancement of photocatalytic disinfection on aligned $\mathrm{TiO}_{2}$ and nitrogen doped $\mathrm{TiO}_{2}$ nanotubes. Molecules 2017, 22,704 . [CrossRef]

55. Nie, X.; Li, G.; Wong, P.K.; Zhao, H.; An, T. Synthesis and characterization of N-doped carbonaceous/TiO 2 composite photoanodes for visible-light photoelectrocatalytic inactivation of Escherichia coli K-12. Catal. Today 2014, 230, 67-73. [CrossRef]

56. Zhang, G.; Zhang, Z.; Xia, D.; Qu, Y.; Wang, W. Solar driven self-sustainable photoelectrochemical bacteria inactivation in scale- up reactor utilizing large-scale fabricable Ti/ $\mathrm{MoS}_{2} / \mathrm{MoO}_{\mathrm{x}}$ photoanode. J. Hazard. Mater. 2020, 392, 122292. [CrossRef]

57. Kim, J.Y.U.; Bessegato, G.G.; de Souza, B.C.; da Silva, J.J.; Zanoni, M.V.B. Efficient treatment of swimming pool water by photoelectrocatalytic ozonation: Inactivation of Candida parapsilosis and mineralization of benzophenone-3 and urea. Chem. Eng. J. 2019, 378, 122094. [CrossRef]

58. Brugnera, M.F.; Miyata, M.; Fujimura Leite, C.Q.; Zanoni, M.V.B. Silver ion release from electrodes of nanotubes of TiO 2 impregnated with Ag nanoparticles applied in photoelectrocatalytic disinfection. J. Photochem. Photobiol. A Chem. 2014, 278, 1-8. [CrossRef]

59. Domínguez-Espíndola, R.B.; Bruguera-Casamada, C.; Silva-Martínez, S.; Araujo, R.M.; Brillas, E.; Sirés, I. Photoelectrocatalytic inactivation of Pseudomonas aeruginosa using an Ag-decorated $\mathrm{TiO}_{2}$ photoanode. Sep. Purif. Technol. 2019, 208, 83-91. [CrossRef]

60. Jang, J.; Hur, H.; Sadowsky, M.; Byappanahalli, M.; Yan, T.; Ishii, S. Environmental Escherichia coli: Ecology and public health implications-A review. J. Appl. Microbiol. 2017, 123, 570-581. [CrossRef]

61. Ishii, S.; Sadowsky, M.J. Escherichia coli in the environment: Implications for water quality and human health. Microbes Environ. 2008, 23, 101-108. [CrossRef] [PubMed]

62. Egerton, T.A.; Christensen, P.A.; Kosa, S.A.M.; Onoka, B.; Harper, J.C.; Tinlin, J.R. Photoelectrocatalysis by titanium dioxide for water treatment. Int. J. Environ. Pollut. 2006, 27, 2-19. [CrossRef]

63. Marugán, J.; Christensen, P.; Egerton, T.; Purnama, H. Synthesis, characterization and activity of photocatalytic sol-gel TiO 2 powders and electrodes. Appl. Catal. B Environ. 2009, 89, 273-283. [CrossRef]

64. Li, G.; Liu, X.; Zhang, H.; An, T.; Zhang, S.; Carroll, A.R.; Zhao, H. In situ photoelectrocatalytic generation of bactericide for instant inactivation and rapid decomposition of Gram-negative bacteria. J. Catal. 2011, 277, 88-94. [CrossRef]

65. Plewa, M.J.; Simmons, J.E.; Richardson, S.D.; Wagner, E.D. Mammalian cell cytotoxicity and genotoxicity of the haloacetic acids, a major class of drinking water disinfection by-products. Environ. Mol. Mutagen. 2010, 51, 871-878. [CrossRef] [PubMed]

66. Malayeri, A.H.; Mohseni, M.; Cairns, B.; Bolton, J.R.; Barbeau, B.; Wright, H.; Linden, K.G. Fluence (UV Dose) required to achieve incremental log inactivation of bacteria, protozoa, viruses and algae. IUVA News 2016, 18, 4-6.

67. Baram, N.; Starosvetsky, D.; Starosvetsky, J.; Epshtein, M.; Armon, R.; Ein-Eli, Y. Enhanced photo-efficiency of immobilized TiO 2 catalyst via intense anodic bias. Electrochem. Commun. 2007, 9, 1684-1688. [CrossRef]

68. Li, G.; Nie, X.; Chen, J.; Wong, P.K.; An, T.; Yamashita, H.; Zhao, H. Enhanced simultaneous PEC eradication of bacteria and antibiotics by facilely fabricated high-activity $\{001\}$ facets $\mathrm{TiO}_{2}$ mounted onto $\mathrm{TiO}_{2}$ nanotubular photoanode. Water Res. 2016, 101, 597-605. [CrossRef] [PubMed]

69. Jiang, Q.; Yin, H.; Li, G.; Liu, H.; An, T.; Wong, P.K.; Zhao, H. Elimination of antibiotic-resistance bacterium and its associated/dissociative blaTEM-1 and aac (3)-II antibiotic-resistance genes in aqueous system via photoelectrocatalytic process. Water Res. 2017, 125, 219-226. [CrossRef]

70. Macak, J.M.; Sirotna, K.; Schmuki, P. Self-organized porous titanium oxide prepared in $\mathrm{Na}_{2} \mathrm{SO}_{4} / \mathrm{NaF}$ electrolytes. Electrochim. Acta 2005, 50, 3679-3684. [CrossRef]

71. Mesones, S.; Mena, E.; López Muñoz, M.J.; Adán, C.; Marugán, J. Synergistic and antagonistic effects in the photoelectrocatalytic disinfection of water with $\mathrm{TiO}_{2}$ supported on activated carbon as a bipolar electrode in a novel 3D photoelectrochemical reactor. Sep. Purif. Technol. 2020, 247, 117002. [CrossRef]

72. Rahmawati, F.; Kusumaningsih, T.; Hapsari, A.M.; Hastuti, A. Ag and Cu loaded on $\mathrm{TiO}_{2}$ /graphite as a catalyst for Escherichia coli-contaminated water disinfection. Chem. Pap. 2010, 64, 557-565. [CrossRef] 
73. He, H.; Sun, S.; Gao, J.; Huang, B.; Zhao, T.; Deng, H.; Wang, X.; Pan, X. Photoelectrocatalytic simultaneous removal of $17 \alpha-$ ethinylestradiol and E. coli using the anode of $\mathrm{Ag}$ and $\mathrm{SnO}_{2}-\mathrm{Sb} 3 \mathrm{D}$-loaded $\mathrm{TiO}_{2}$ nanotube arrays. J. Hazard. Mater. 2020, 398, 122805. [CrossRef]

74. Gupta, R.; Modak, J.M.; Madras, G. Behavioral analysis of simultaneous photo-electro-catalytic degradation of antibiotic resistant: E. coli and antibiotic via ZnO/CuI: A kinetic and mechanistic study. Nanoscale Adv. 2019, 1, 3992-4008. [CrossRef]

75. Trofa, D.; Gácser, A.; Nosanchuk, J.D. Candida parapsilosis, an emerging fungal pathogen. Clin. Microbiol. Rev. 2008, 21, 606-625. [CrossRef]

76. Diab-Elschahawi, M.; Forstner, C.; Hagen, F.; Meis, J.F.; Lassnig, A.M.; Presterl, E.; Klaassen, C.H.W. Microsatellite genotyping clarified conspicuous accumulation of Candida parapsilosis at a cardiothoracic surgery intensive care unit. J. Clin. Microbiol. 2012, 50, 3422-3426. [CrossRef]

77. Döğen, A.; Sav, H.; Gonca, S.; Kaplan, E.; Ilkit, M.; Babič, M.N.; Gunde-Cimerman, N.; De Hoog, G.S. Candida parapsilosis in domestic laundry machines. Med Mycol. 2017, 55, 813-819. [CrossRef]

78. Chu, C.; Ryberg, E.C.; Loeb, S.K.; Suh, M.J.; Kim, J.H. Water disinfection in rural areas demands unconventional solar technologies. Acc. Chem. Res. 2019, 52, 1187-1195. [CrossRef] [PubMed]

79. Pires, R.H.; Brugnera, M.F.; Zanoni, M.V.B.; Giannini, M.J.S.M. Effectiveness of photoelectrocatalysis treatment for the inactivation of Candida parapsilosis sensu stricto in planktonic cultures and biofilms. Appl. Catal. A Gen. 2016, 511, 149-155. [CrossRef]

80. Souza, B.C.A.; Guaraldo, T.T.; Brugnera, M.F.; Pires, R.H.; Giannini, M.J.S.M.; Zanoni, M.V.B. Antifungal properties of high efficient $\mathrm{W} / \mathrm{WO}_{3}$ electrodes acting under UV-Vis and visible light and chloride medium. J. Braz. Chem. Soc. 2017, 28, 2084-2093. [CrossRef]

81. Haig, S.J.; Kotlarz, N.; Lipuma, J.J.; Raskin, L. A high-throughput approach for identification of nontuberculous mycobacteria in drinking water reveals relationship between water age and Mycobacterium avium. mBio 2018, 9, 1-13. [CrossRef] [PubMed]

82. Falkinham, J.O. Surrounded by mycobacteria: Nontuberculous mycobacteria in the human environment. J. Appl. Microbiol. 2009, 107, 356-367. [CrossRef]

83. Kulkarni, P.; Olson, N.D.; Paulson, J.N.; Pop, M.; Maddox, C.; Claye, E.; Rosenberg Goldstein, R.E.; Sharma, M.; Gibbs, S.G.; Mongodin, E.F.; et al. Conventional wastewater treatment and reuse site practices modify bacterial community structure but do not eliminate some opportunistic pathogens in reclaimed water. Sci. Total Environ. 2018, 639, 1126-1137. [CrossRef]

84. Brugnera, M.F.; Miyata, M.; Zocolo, G.J.; Leite, C.Q.F.; Zanoni, M.V.B. Inactivation and disposal of by-products from Mycobacterium smegmatis by photoelectrocatalytic oxidation using $\mathrm{Ti} / \mathrm{TiO}_{2}-\mathrm{Ag}$ nanotube electrodes. Electrochim. Acta 2012, 85, 33-41. [CrossRef]

85. Brugnera, M.F.; Miyata, M.; Zocolo, G.J.; Leite, C.Q.F.; Zanoni, M.V.B. Ti/ $\mathrm{TiO}_{2}$ nanotubes enhance Mycobacterium fortuitum, Mycobacterium chelonae and Mycobacterium abscessus inactivation in water. J. Chem. Technol. Biotechnol. 2014, 89, 1686-1696. [CrossRef]

86. Brugnera, M.F.; Miyata, M.; Zocolo, G.J.; Gonçalves Tessaro, L.L.; Fujimura Leite, C.Q.; Boldrin Zanoni, M.V. A promising technology based on photoelectrocatalysis against Mycobacterium tuberculosis in water disinfection. Environ. Technol. 2021, 42, 743-752. [CrossRef]

87. Fraga, L.E.; Anderson, M.A.; Beatriz, M.L.P.M.A.; Paschoal, F.M.M.; Romão, L.P.; Zanoni, M.V.B. Evaluation of the photoelectrocatalytic method for oxidizing chloride and simultaneous removal of microcystin toxins in surface waters. Electrochim. Acta 2009, 54, 2069-2076. [CrossRef]

88. Rice, D.; Westerhoff, P.; Perreault, F.; Garcia-Segura, S. Electrochemical self-cleaning anodic surfaces for biofouling control during water treatment. Electrochem. Commun. 2018, 96, 83-87. [CrossRef]

89. Rice, D.; Rajwade, K.; Zuo, K.; Bansal, R.; Li, Q.; Garcia-Segura, S.; Perreault, F. Electrochemically-active carbon nanotube coatings for biofouling mitigation: Cleaning kinetics and energy consumption for cathodic and anodic regimes. J. Colloid Interface Sci. 2021, 603, 391-397. [CrossRef]

90. Brillas, E.; Garcia-Segura, S. Benchmarking recent advances and innovative technology approaches of Fenton, photo-Fenton, electro-Fenton, and related processes: A review on the relevance of phenol as model molecule. Sep. Purif. Technol. 2020, 237, 116337. [CrossRef]

91. Long, Y.; Ni, J.; Wang, Z. Subcellular mechanism of Escherichia coli inactivation during electrochemical disinfection with boron-doped diamond anode: A comparative study of three electrolytes. Water Res. 2015, 84, 198-206. [CrossRef]

92. Chen, Y.; Li, S.; Hu, J. Photoelectrocatalytic degradation of organics and formation of disinfection byproducts in reverse osmosis concentrate. Water Res. 2020, 168, 115105. [CrossRef] [PubMed] 